\title{
Depositional history of estuarine infill during the last postglacial transgression (Gulf of Cadiz, Southern Spain)
}

\author{
Cristino J. Dabrio ${ }^{a, *}$, Cari Zazo ${ }^{b}$, José L. Goy ${ }^{c}$, Francisco J. Sierro ${ }^{c}$, \\ Francisco Borja $^{d}$, Javier Lario ${ }^{b}$, José A. González ${ }^{c}$, José A. Flores ${ }^{c}$ \\ ${ }^{a}$ Facultad de Ciencias Geologicas, Departamento de Estratigrafia and Instituto de Geología Económica-CSIC, Universidad Complutense. \\ 28040 Madrid, Spain \\ b Departamento de Geología, Museo Nacional de Ciencias Naturales-CSIC, 28006 Madrid, Spain \\ "Departamento de Geologia, Facultad de Ciencias, Universidad, 37008 Salamanca, Spain \\ 'Area de Geografia Fisica, Facultad de Humanidades, Universidad, 21007 Huelva, Spain
}

\begin{abstract}
The Late Pleistocene and Holocene evolution of the estuaries in the Gulf of Cadiz is interpreted for the first time using drill cores, logs, trenches, and 38 new radiocarbon data, and the results compared with the shelf. The Odiel, Tinto and Guadalete Rivers deposited conglomerates during a highstand that did not reach the present sea level dated at ca. 25-30 ka (Isotopic Stage (IS) 3), corresponding to a relatively humid period in the area. Rivers incised these coarse-grained deposits during the last main lowstand at $\mathrm{ca} .18 \mathrm{ka}$, when sea level dropped to $-120 \mathrm{~m}$ and the coastline lay $14 \mathrm{~km}$ seawards from the present. The erosional surface is a sequence boundary and the flooding surface of the postglacial eustatic rise, overlain by the valley fill deposits of the transgressive and highstand phases of the last fourth- and fifth-order depositional sequences recognised in the shelf. The first marine influence in the estuaries during the transgression occurs at $-25 /-30 \mathrm{~m}$ at ca. 10,000 years BP. According to fossil assemblages, the transgressed basins changed from brackish to more open marine as the sea rose until ca. 6500 years BP, when it reached the maximum flooding and the sandy estuarine barriers ceased to retrograde toward the muddy central basins. Then, the rate of eustatic rise decreased drastically, and the estuarine filling followed a two-fold pattern governed by the progressive change from vertical accretion to lateral (centripetal) progradation. At ca. 4000 years BP the fluvial input surpassed the already negligible rate of rise, causing partial emergence of tidal flats and spit barriers in the largely filled estuarine basins. Prevalence of coastal progradation upon vertical accretion at ca. 2400 years BP caused accelerated expansion of tidal flats and rapid growth of the sandy barriers. Further changes since the 16th century reflect widespread anthropic impacts.
\end{abstract}

Keywords: incised-valley fill; estuary; Flandrian transgression; Late Pleistocene-Holocene; radiocarbon data; coastal evolution 


\section{Introduction}

Along the coast of the Gulf of Cadiz (southwestern Iberian Peninsula) there are several estuaries partly enclosed by spits (Fig. 1). The sedimentary history of the estuarine filling is still poorly understood despite a few publications describing the physiography and recent deposits of the estuaries of the Rivers Guadiana (Morales, 1993, 1997), Piedras (Borrego et al., 1993) and Odiel (Borrego, 1992; Borrego et al., 1997; Pendón et al., 1998). Study of drill cores in the Guadalete estuary allowed Dabrio et al. (1995) and Goy et al. (1996) to recognise an initial phase of flooding in the early Holocene followed by a phase of open estuary and a later, relatively rapid, filling related to variable stages of sea level and progradation of the Guadalete River delta after $6450{ }^{14} \mathrm{C}$ years BP.

Most of the previous recent research of the coastal areas has focused on the study of coastal morphology and evolution with particular interest in the factors controlling changes of sea level and climatic signals recorded in coastal deposits (Suárez Bores, 1971: Menanteau, 1979; Dabrio and Polo, 1987; Rodríguez Vidal, 1987; Zazo et al., 1992, 1993, 1994a,b, 1996a,b; Lario, 1996; Rodríguez Ramírez et al., 1996; Zazo et al., 1997a,b). A major advance has been the recognition and refinement of a chronology of events of progradation and erosion of beaches after the transgressive maximum in the area (ca. $6500{ }^{14} \mathrm{C}$ years BP, Zazo et al., 1994a). In the best developed case (Goy et al., 1996, 1998), found in the Atlantic-Mediterranean linkage area (Roquetas, SE Spain, Western Mediterranean), each spit barrier system includes four morpho-sedimentary units named spit barrier units $\mathrm{H}_{1}$ to $\mathrm{H}_{4}$. Discrete sets of beach crests and swales on the surface of each unit are separated by erosional surfaces and/or particularly large swales called gaps. Archaeological evidence (Gómez Ponce et al., 1997) coupled to a fast-growing database of normalised ages (Zazo et al., 1994a; Lario et al., 1995; Dabrio et al., in press) including correction of reservoir effect allowed us to obtain the calibrated ages (Goy et al., 1998; Borja et al., 1999) used in this paper: $\mathrm{H}_{1}\left(6550-4400{ }^{14} \mathrm{C}\right.$ years $\mathrm{BP}$ or $6500-4700$ cal. BP), $\mathrm{H}_{2}\left(4200-2550{ }^{14} \mathrm{C}\right.$ years $\mathrm{BP}$ or $4400-2700 \mathrm{cal}$. BP), $\mathrm{H}_{3}\left(2300-800{ }^{14} \mathrm{C}\right.$ years $\mathrm{BP}$ or 2400-700 cal. BP), and $\mathrm{H}_{4}$ (the last 500 years or
$500 \mathrm{cal}$. BP-present). The suite is incomplete in the study area where $\mathrm{H}_{1}$ has not been located in outcrops.

There are also a number of papers dedicated to the physiography, marine geology and sedimentation in the continental shelf of the Gulf of Cadiz (Vanney and Menanteau, 1985; Gutiérrez-Más et al., 1994; Hernández-Molina et al., 1994; Somoza et al., 1997; van Geen et al., 1997; Maldonado and Nelson, 1999; Nelson and Maldonado, 1999; Nelson et al., 1999; Rodero et al., 1999). However, these papers did not fully extend their observations to the coastal areas were the studied incised-valleys occur.

Thus, this paper attempts to study the generation and filling of two incised-valleys in the course of the last postglacial transgression using the current concepts of sequence stratigraphy as in Mitchum et al. (1977), Vail et al. (1977), van Wagoner et al. (1988), and Roy (1994). The paper relates the architecture of the estuarine fill with glacio-eustasy (global sea level rise) and the sum of more local factors including the morphology of the pre-existing landscape, the sediment budget, and the rate of rise of sea level. The paper connects the evolutions of estuaries and the continental shelf off the Gulf of Cadiz, and offers a reference for similar studies in other mesotidal settings.

\section{Geological setting}

The coast of the Gulf of Cadiz (southern Iberian Peninsula) can be described as semidiurnal mesotidal (Borrego et al., 1993) with mean tidal ranges of 2.1 $\mathrm{m}$. Wave energy is medium, because $75 \%$ of the waves do not exceed $0.5 \mathrm{~m}$ in height. Due to the morphology of the coast (Fig. 1), most of the wavefronts approach the coast obliquely inducing longshore transport and littoral drift toward the east and southeast on the Spanish side of the Gulf of Cadiz. These conditions favour the development of broad littoral lowlands, usually sheltered by spits, where tidal flats and fresh water marshes extend several kilometers inland. As the spit barrier systems closing the estuaries offered favourable settings for human settlements, archaeological setting and remains are relatively frequent. 


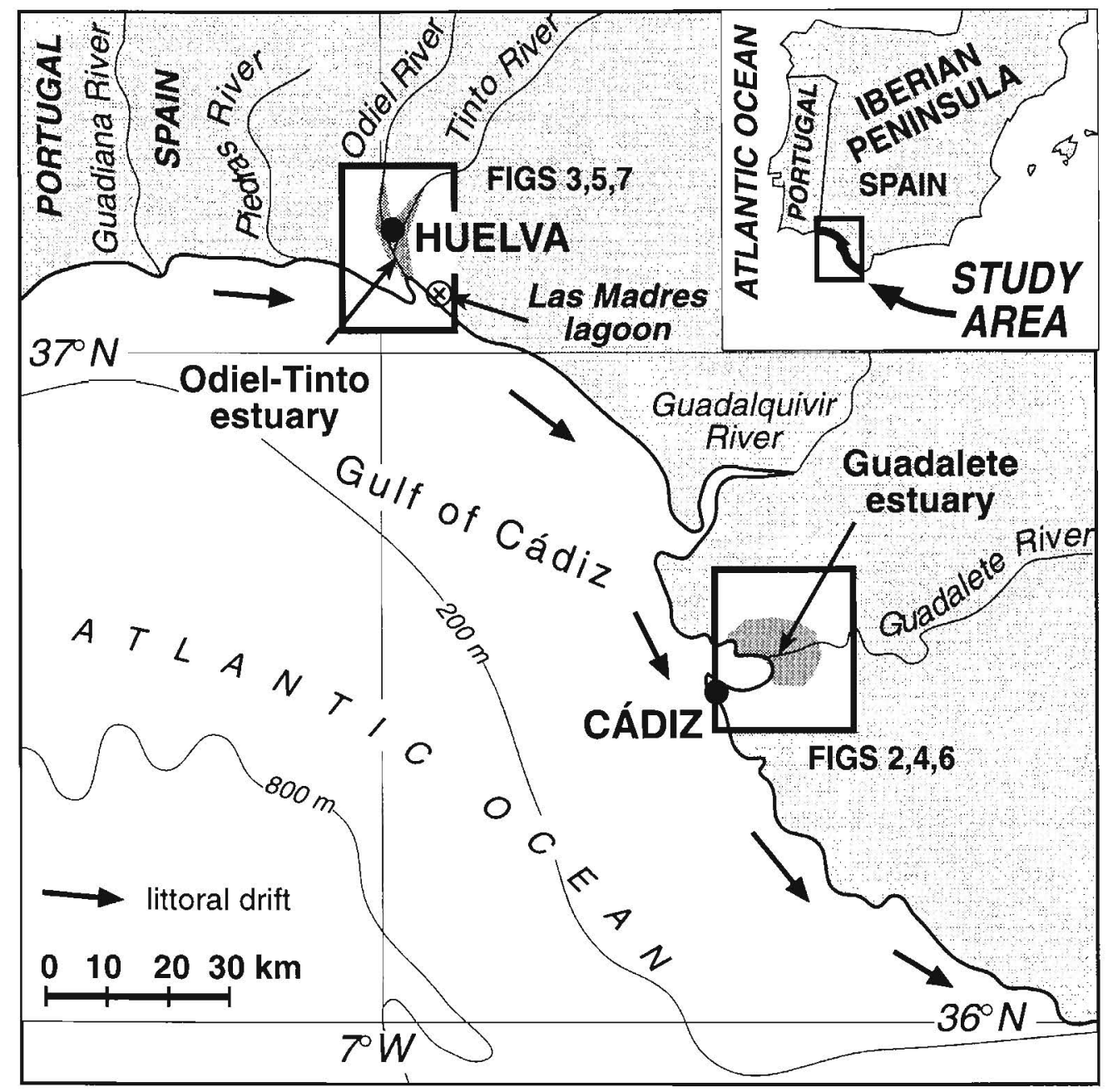

Fig. 1. Map showing study areas, fluvial valleys and estuary settings in the Gulf of Cadiz.

The rivers flowing into the Gulf of Cadiz during the fall of sea level of the last glacial period excavated incised-valleys, two of which are studied in this paper: the Odiel-Tinto and the Guadalete. During the succeeding rise of sea level a part of the incised-valley of the Guadalete River evolved into a wave-dominated estuary, whereas the estuarine part of the Odiel and Tinto River valleys was mixed tideand wave-dominated. At present, both estuaries are largely filled with sediments. It is worth indicating that we follow the concepts and definitions of incised-valley systems, valley fill, estuary fill, and estuary models used by Allen (1991), Allen and Posamentier (1993; 1994), Dalrymple et al. (1992; 1994), and Zaitlin et al. (1994).

The Late Quaternary pattern of sedimentary facies on the inner continental shelf of the Gulf of Cadiz, above $300 \mathrm{~m}$ water depth, results from an interaction between a number of controlling factors. These are dominated by the Atlantic inflow currents flowing toward the southeast across the Cadiz shelf toward the Strait of Gibraltar (Nelson et al., 1999). The margin growth is mainly controlled by highfrequency, fourth-order (100 ka) glacio-eustatic fluc- 
tuations and takes place mainly during sea level falls and lowstands (Chiocci et al., 1997; Somoza et al., 1997; Rodero et al., 1999)

\section{Techniques}

We have identified and mapped shallow-marine and coastal deposits integrating them into morphosedimentary units using sedimentological, faunal and tectonic data. Radiometric methods and archaeological information supplied age data.

Spit deposits were sampled in cross-section digging trenches to reach the upper foreshore or berm facies, close to mean sea level (MSL) where shells of the mollusc Glycymeris glycymeris are relatively common. We drilled the estuaries and the peat bog to study lithology and facies, and to collect samples for laboratory analyses. We reached up to $8 \mathrm{~m}$ depth with manual and percussion mechanical drills, but continuous cores of up to $40 \mathrm{~m}$ deep geotechnical boreholes drilled with conventional mechanical rotation rigs were available as well. Specifically, we measured 13 continuous drill cores and over 30 trenches, 2 to $5 \mathrm{~m}$ deep, dug in Huelva for building foundations, and re-interpreted 62 drill $\operatorname{logs}$ and an unpublished set of subsurface geotechnical lithology maps based on drillings bored in the 1960s in Valdelagrana spit (Figs. 4 and 5). All these data allowed us to make the first comprehensive sedimentary interpretation and subsurface facies analysis of these estuaries.

We use ${ }^{14} \mathrm{C}$ years $\mathrm{BP}$ ages, normalised and corrected for the marine reservoir effect. We calculated the reservoir effect in the study area as $-440 \pm 85$ ${ }^{14} \mathrm{C}$ years BP by means of two accelerator mass spectrometry (AMS) ablation probes carried out on organic material and on a shell collected in the same layer of a core drilled in the lower reaches of the Guadalquivir River.

Palaeontological studies included taphonomy (fragmentation, abrasion, bioerosion, and bioencrustation), palaeoecology of macrofauna and microfauna, and analysis of pollen and diatoms. Studies of the vertical variation of fossil content within the cores have been very rewarding, except diatoms that did not yield consistent results.
Stable isotopes $\left(\delta \mathrm{PDB}^{18} \mathrm{O}\right.$ and $\left.\delta \mathrm{PDB}^{13} \mathrm{C}\right)$ were studied with mass spectrometry in more than 40 samples of well-preserved shells of the benthic foraminifer Ammonia sp. without internal fill.

\section{Lithostratigraphy and environmental interpre- tation of the Guadalete and Odiel-Tinto incised- valley fills}

The wave-dominated estuary of the Guadalete River is roughly circular and is at present separated from the sea by the complex Valdelagrana spit (Fig. 2).

In contrast, the confluence of the Odiel and Tinto Rivers at Huelva town forms a complex bifurcate, mixed tide- and wave-dominated estuary, partly enclosed by the spit systems of Punta Arenilla and Punta Umbría. Both branches are funnel-shaped and the Odiel and Tinto Rivers have deposited bayhead deltas at the northern extremities of the valleys (Fig. 3). Active tidal flats occur, nowadays, only south of Saltés Island (Borrego, 1992).

\subsection{Pre-estuarine fuvial sediments}

Underlying the Holocene estuarine deposits is a lithosome of fluvial sediments (Figs. 4 and 5). It consists of a fining-upwards pile of well-rounded yellow polygenetic conglomerates with predominantly quartzite pebbles up to $0.10 \mathrm{~m}$ in diameter, sandstones with interbedded gravel layers, and mudstones. Dominant colours are yellow and greenish, with vertically elongated leached zones interpreted as root casts. Carbonate nodules, locally elongated vertically, and having botryoidal shapes are also frequent. We interpret this succession as deposited by a mixed-load braided river, with more or less swampy flood plains.

We collected some samples of wood fragments from a mudstone layer in the middle part of the fluvial interval for AMS radiometric dating, and obtained ages of ca. 25,000 to $30,000{ }^{14} \mathrm{C}$ years BP (Table 1 and Fig. 5), i.e., Late Isotopic Stage (IS) 3.

The upper limit of the fluvial deposits is an irregular erosional surface as deduced from correlation of drill cores. Sections across the relatively narrow fluvial valleys show that the deepest part of 


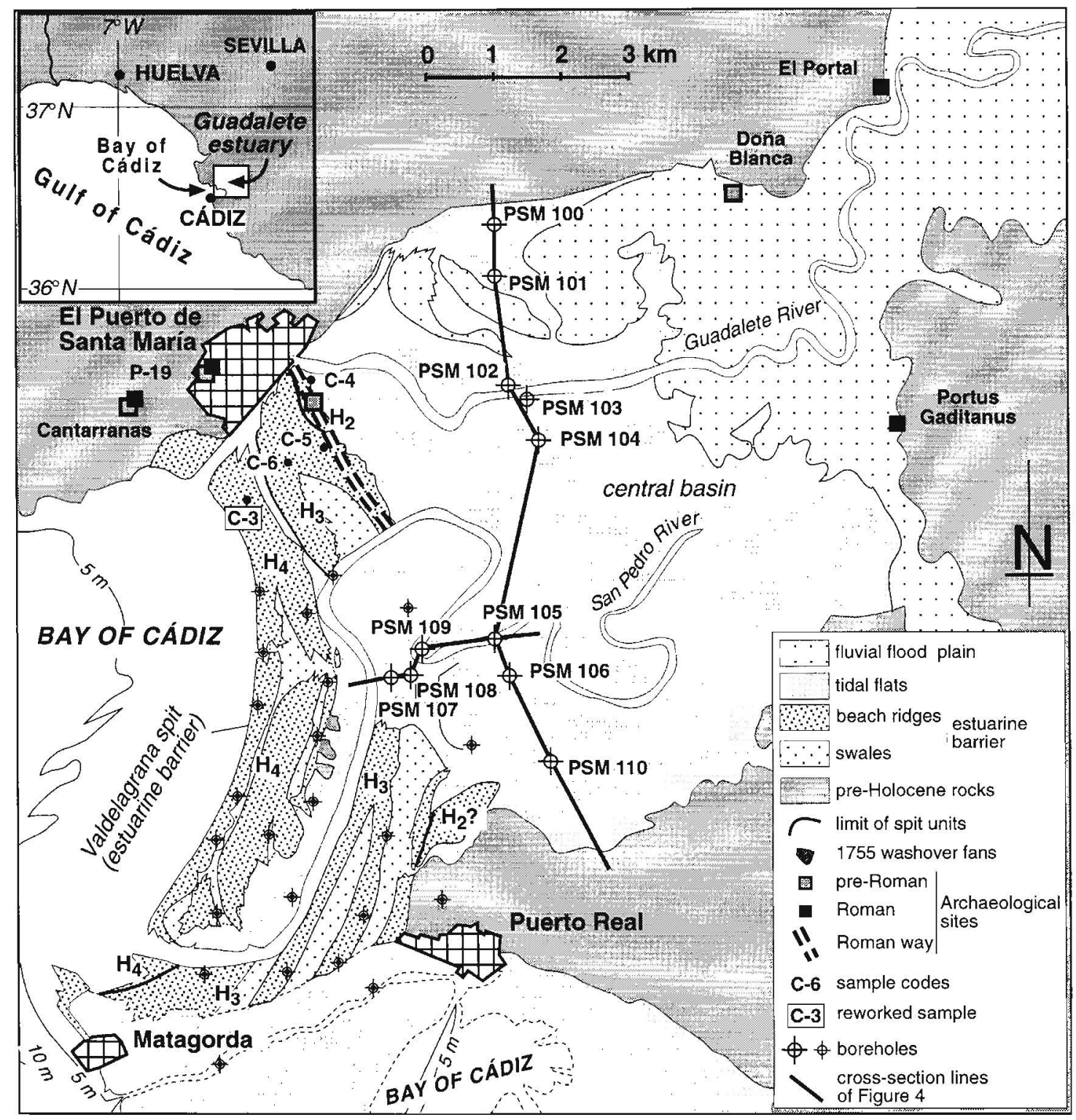

Fig. 2. The Guadalete estuary and Valdelagrana spit system. Heavy lines separate spit units $\left(\mathrm{H}_{2}\right.$ to $\left.\mathrm{H}_{4}\right)$. PSM: Puerto de Santa María drillings. Archaeological sites after Rambaud (1996) and Borja (1997).

the incision tends to occur towards the east and southeast of the axis of the present estuaries (Figs. 4 and 5). We interpret this morphological pattern as the reflection of underlying fault lines that control the main river courses in the area (Zazo et al., 1994b). We relate the erosional surface to fluvial incision during the last glacial period, when the sea level dropped $120 \mathrm{~m}$ in the Gulf of Cadiz continental shelf (Hernández-Molina et al., 1994). The resulting surface is a type-1 sequence boundary of van Wagoner et al. (1988).

During the ensuing transgression a part of the valleys was flooded and estuarine deposition took place during the transgressive and the highstand 


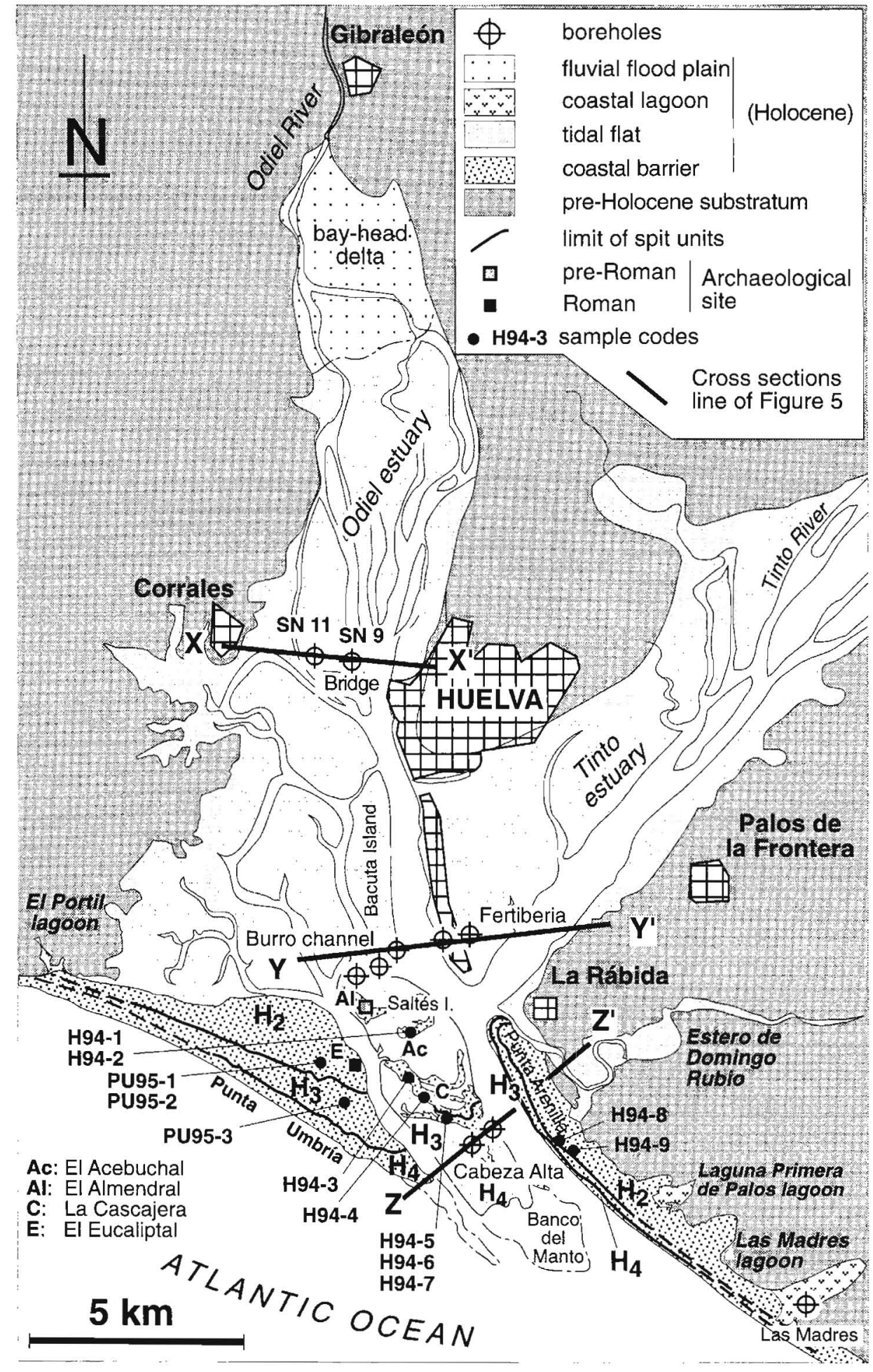


phases (TST and HST, respectively) of a highfrequency eustatic cycle. The estuary fill includes several facies briefly described below.

\subsection{Transgressive fluvial and marine facies}

The first, topographically lower $(-25$ to -30 $\mathrm{m}$ ), evidence of marine conditions overlaying the sequence boundary is a layer of grey sands with fragments of Scaphopoda and Balanidae found in Guadalete estuary only. In some places there are interbedded layers of non-fossiliferous yellow gravel and sand, very much like the previously described fluvial deposits. It is capped by grey-greenish mudstones with abundant plant debris that form discrete peat layers of centimeter thickness. The absence of rootlets at the base of the peat layers, suggests that they are allochthonous. Radiometric dating of peat layers indicates an early Holocene age (samples PSM104/C20: $8195 \pm 100$, and PSM104/C21: $9465 \pm 340{ }^{14} \mathrm{C}$ years BP, Table 1 ). This unit has not been recognised in the Odiel-Tinto estuary, where the age of the transgression must be younger due to the higher topographical elevation (i.e., closer to present MSL) of the basal erosional surface.

We interpret that the alternating marine and fluvial deposits record a somewhat imprecise limit of terrestrial and coastal environments during the fluctuating postglacial rise of sea level. They occur in the topographically lowest parts of the incised-valley, which were the first to be flooded during the transgression. Therefore, these deposits can be considered as a largely reworked and transgressed, rudimentary bayhead delta, and the basal erosional surface records in most places the sequence boundary and the transgressive surface.

In Guadalete estuary, the upper limit of the transgressive fluvial and marine unit is a channel-shaped erosional surface that we interpret as the initial flooding surface (cf. Allen and Posamentier, 1994).

\subsection{Mud facies of the central basin (transgressive and highstand deposits)}

The lower, deepest part of the estuary fill (for instance, between 25 and $21.7 \mathrm{~m}$ depth in core PSM104) consists of well-sorted grey to greenish mudstone (medium grain size $0.004-0.002 \mathrm{~mm}$ ) with plant debris and scattered, usually complete, mollusc shells. No internal structure was observed with the naked eye. However, changes in stable isotope and faunal contents, in particular, percentages of the benthic foraminifers Haynesina germanica and Elphidium excavatum indicative of restricted waterconditions, allow to distinguish two facies.

The older, stratigraphically lower, facies shows low diversity in fossil content (for instance, between 25 and $23.4 \mathrm{~m}$ in core PSM104). It consists of high percentages of $H$. germanica and $E$. excavatum and plant debris, but only some scattered fragments of Cardidae and Rissoidae. This assemblage indicates poor communication with the open sea that we interpret as caused by a relatively high fresh water input, most probably related to transgression.

The upper facies (23.4 to $21.7 \mathrm{~m}$ in core PSM104) bears a more varied and richer fauna of miliolids and echinoderms, abundant Bittium reticulatum, Cardium sp. and rissoids, and relatively scarce $H$. germanica and $E$. excavatum. The assemblage records increased influence of normal marine waters. In Odiel-Tinto, a few interbedded layers rich in Donax trunculus, Cardium sp., and Gastrana (?) sp. record more marine conditions that we interpret as reduced input of fresh water, probably indicative of the highstand. Radiometric dating of samples collected from the lowermost fossils found in these deposits, just above the erosional sequence boundary (Fig. 5), indicates

Fig. 3. The Odiel-Tinto estuary and estuarine barrier formed by the spit systems of Punta Arenilla and Punta Umbria, and the complex Saltés Island. Heavy lines separate spit units $\left(\mathrm{H}_{2}\right.$ to $\left.\mathrm{H}_{4}\right)$. Some sites represent several boreholes. Archaeological sites after Borja et al. (1999). 


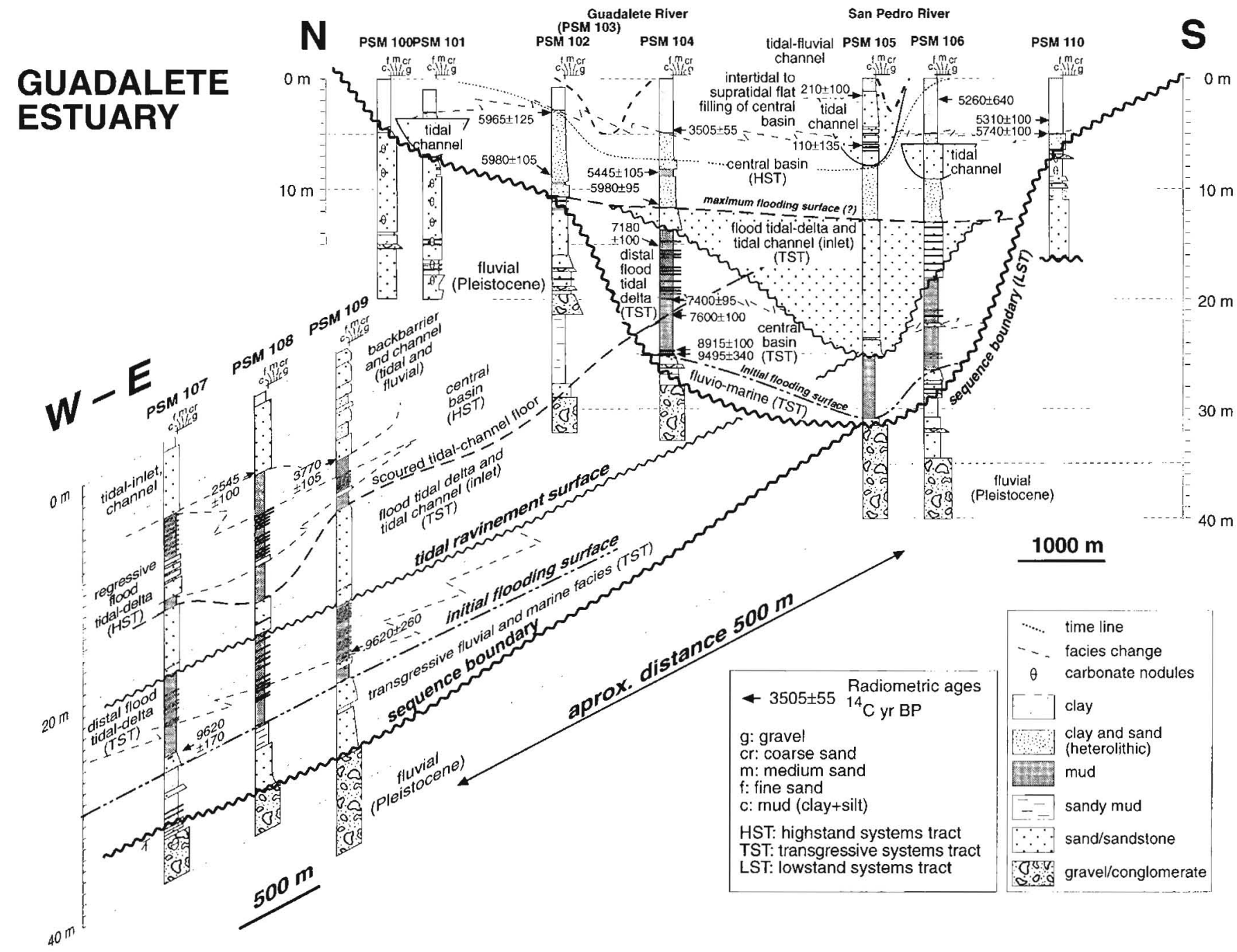

Fig. 4. Cross-sections of the Guadalete incised-valley fill and sequence stratigraphy. Location in Fig. 2. Drill sites are at elevations ranging from 0 to $1.3 \mathrm{~m}$ above MSL which were not taken into account. The datum of the drill logs in figures and Table 1 is the high-tide mark. 


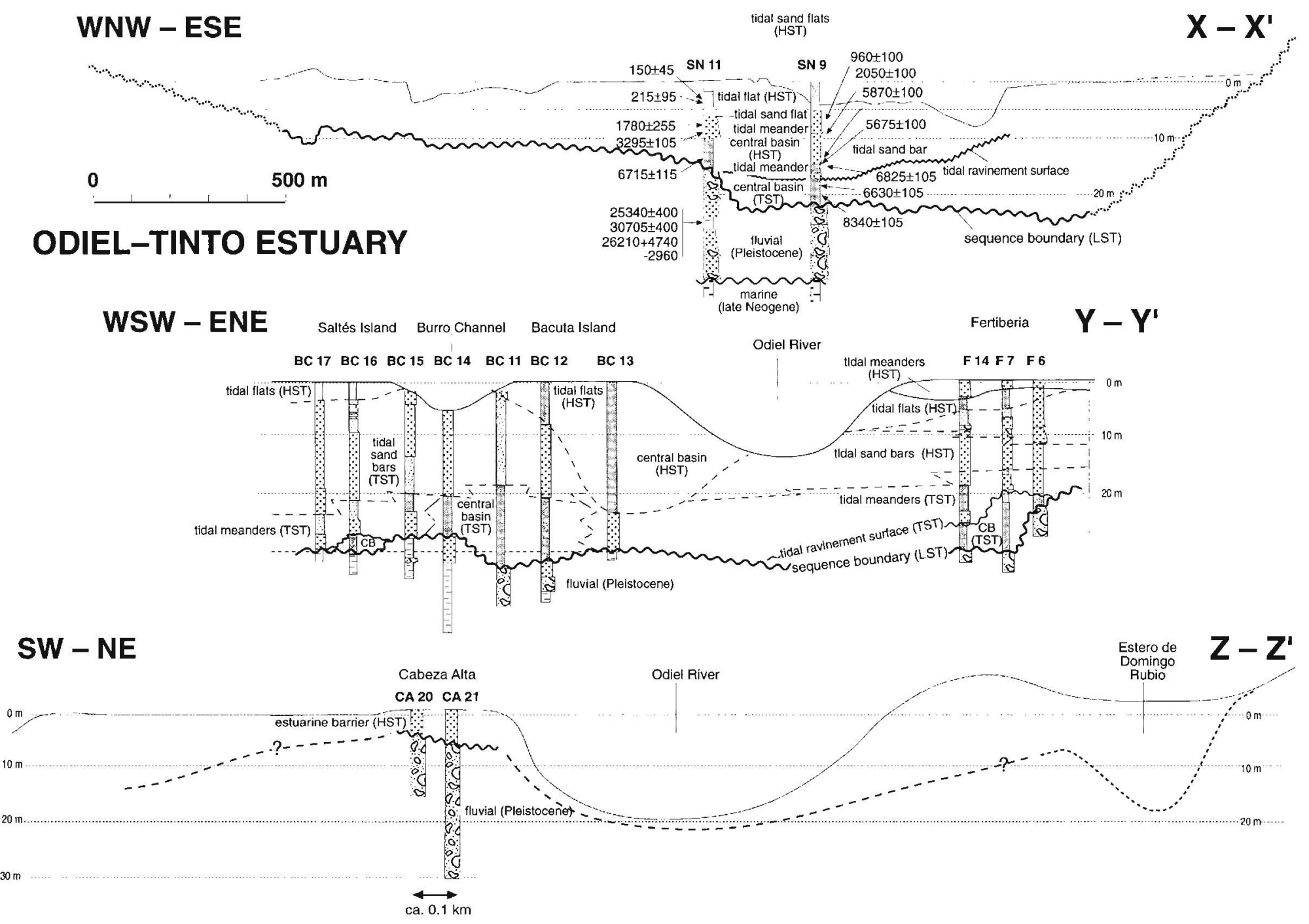

Fig. 5. Cross-sections of the Odiel-Tinto incised-valley fill and sequence stratigraphy. 
Table 1

Database of ${ }^{14} \mathrm{C}$ samples and results. Depths of drill core samples in meters, with datum the high-tide mark, considered as MSL. Depths of samples collected in trenches referred to MSL. Positive values in Laguna de Las Madres peat bog indicate elevations above MSL. Laboratories: GX: Geochron Laboratories, Krueger, Cambridge (USA); IRPA: Institute Royal du Patrimoine Artistique, Brussels (Belgium); LGQ: Laboratoire du Geologie du Quaternaire, CNRS, Marseille (France); R: Centro di Studio per la Geodinamica Applicata a la Stratigrafia Recente, CNR Dipartamento Fisica, Universita 'La Sapienza', Roma (Italy); UtC: Utrecht Van der Graff (The Netherlands). References: (1) Goy et al., 1996; (2) Dabrio et al., 1995; (3) Zazo et al., 1994a,b; (4) Zazo et al., $1996 \mathrm{~b}$

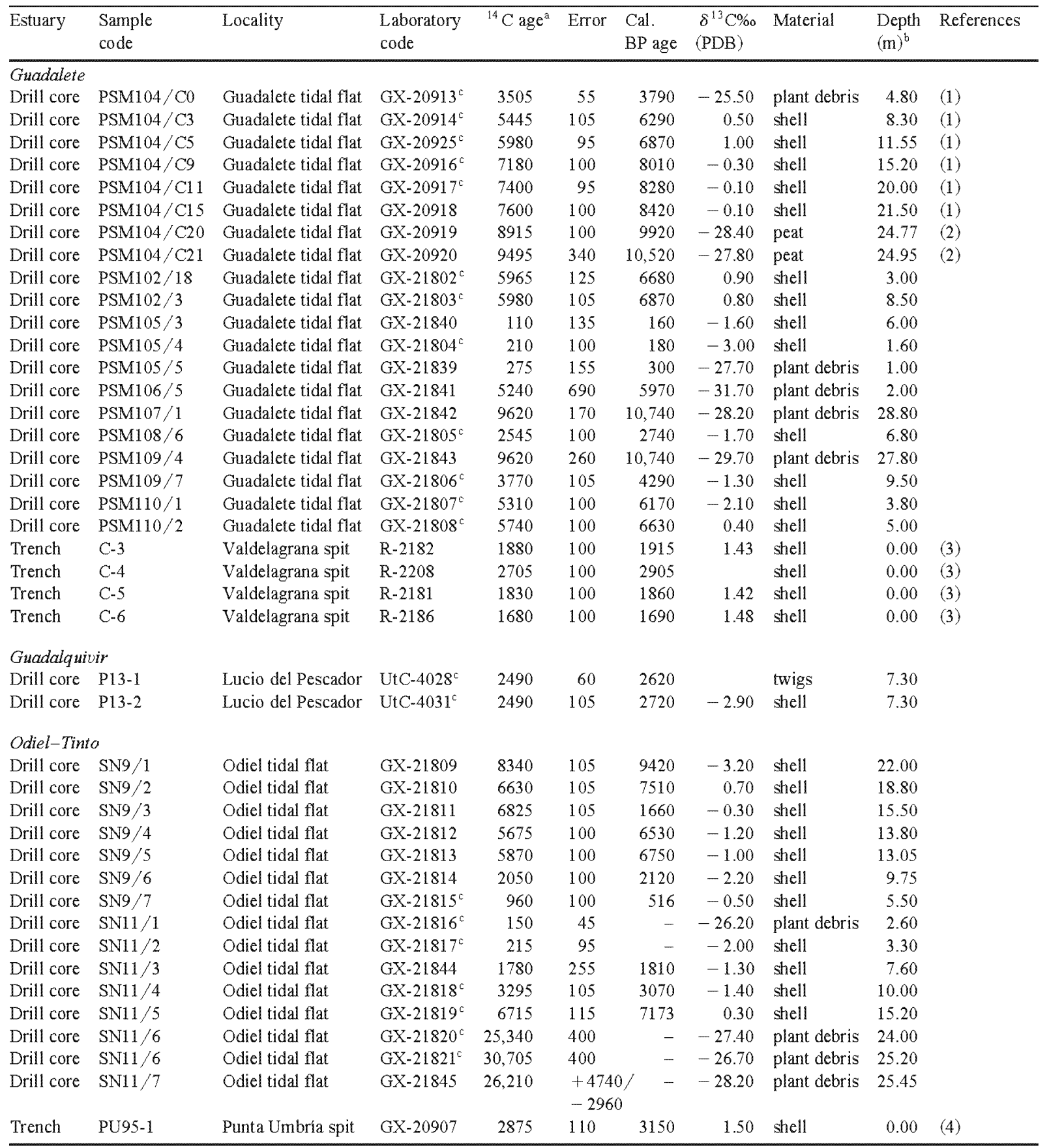


Table 1 (continued)

\begin{tabular}{|c|c|c|c|c|c|c|c|c|c|c|}
\hline Estuary & $\begin{array}{l}\text { Sample } \\
\text { code }\end{array}$ & Locality & $\begin{array}{l}\text { Laboratory } \\
\text { code }\end{array}$ & ${ }^{14} \mathrm{C}$ age ${ }^{\mathrm{a}}$ & Error & $\begin{array}{l}\text { Cal. } \\
\text { BP age }\end{array}$ & $\begin{array}{l}\delta^{13} \mathrm{C} \% \\
(\mathrm{PDB})\end{array}$ & Material & $\begin{array}{l}\text { Depth } \\
(\mathrm{m})^{\mathrm{b}}\end{array}$ & References \\
\hline \multicolumn{11}{|c|}{ Odiel-Tinto } \\
\hline Trench & PU95-3 & Punta Umbría spit & GX-20909 & 1460 & 110 & 1420 & 1.80 & shell & 0.00 & (4) \\
\hline Trench & H94-1 & $\begin{array}{l}\text { El Acebuchal } \\
\text { (Saltés Island) }\end{array}$ & $\mathrm{UtC}-4182^{\circ}$ & 5100 & 110 & 5910 & 1.75 & shell & 0.00 & \\
\hline Trench & H94-3 & $\begin{array}{l}\text { La Cascajera } \\
\text { (Saltes Island) }\end{array}$ & IRPA-1157 & 2705 & 90 & 2905 & 1.74 & shell & 0.00 & \\
\hline Trench & H94-4 & $\begin{array}{l}\text { La Cascajera } \\
\text { (Saltes Island) }\end{array}$ & IRPA-1158 & 2675 & 90 & 2860 & 1.82 & shell & 0.00 & \\
\hline Trench & $\mathrm{H} 94-5$ & $\begin{array}{l}\text { La Cascajera } \\
\text { (Saltés Island) }\end{array}$ & $\mathrm{UtC}-4190^{\circ}$ & 1290 & 105 & 1270 & 1.55 & shell & 0.00 & \\
\hline Trench & H94-8 & Punta Arenilla spit & IRPA-1164 & 2950 & 95 & 3245 & 1.49 & shell & 0.00 & \\
\hline Trench & H94-9 & Punta Arenilla spit & IRPA-1156 & 3220 & 95 & 3555 & 1.30 & shell & 0.00 & \\
\hline Trench & LM-4-C6 & $\begin{array}{l}\text { Las Madres } \\
\text { peat bog }\end{array}$ & LGQ-1021 & 960 & 200 & 910 & & $\begin{array}{l}\text { peaty } \\
\text { sand }\end{array}$ & +5.00 & (5) \\
\hline Trench & LM-4-C7 & $\begin{array}{l}\text { Las Madres } \\
\text { peat bog }\end{array}$ & LGQ-1022 & 1090 & 170 & 970 & & $\begin{array}{l}\text { peaty } \\
\text { sand }\end{array}$ & +4.60 & (5) \\
\hline Trench & $\mathrm{LM}-4-\mathrm{C} 8$ & $\begin{array}{l}\text { Las Madres } \\
\text { peat bog }\end{array}$ & LGQ-1023 & 1150 & 190 & 1060 & & $\begin{array}{l}\text { peaty } \\
\text { sand }\end{array}$ & +4.40 & (5) \\
\hline Drill core & $\begin{array}{l}\text { LM1b } \\
\text { M11 }\end{array}$ & $\begin{array}{l}\text { Las Madres } \\
\text { peat bog }\end{array}$ & UtC- 4029 & 2550 & 60 & 2730 & & peat & +2.00 & (5) \\
\hline
\end{tabular}

${ }^{2}$ Reservoir effect corrected $(-440 \pm 85$ years BP).

${ }^{b}$ With + sign: elevations above MSL.

${ }^{c}$ AMS analysis.

that marine sedimentation began ca. $8340 \pm 105{ }^{14} \mathrm{C}$ years BP.

\subsection{Mudstone and shell layers facies (transgressive distal backbarrier, Guadalete)}

This facies consists of silty clay, with fine silts (grain size $0.015625 \mathrm{~mm}$ ) dominating towards the top. Interbedded layers, typically 2 to $20 \mathrm{~mm}$ thick, of medium to poorly sorted fine and medium sands, and shell accumulations (coquinas), occur irregularly spaced at intervals in the order of tens of centimeters. The species diversity is high, with many remains of Ostrea $\mathrm{sp}$. and $B$. reticulatum, other gastropods, bryozoans, scaphopods, and crustaceans, widely bored by Clyonidae sponges. High percentages of miliolids and echinoderm fragments indicate open marine waters (Fig. 5, interval 20.5 to $13.8 \mathrm{~m}$ ).

According to lithology, faunal content and relative position in the estuary, we interpret the interbedded coarse-grained layers as a distal fringe of washover and flood tidal delta deposits on the landward side of the estuarine barrier (Figs. 2 and 4). At 
ca. 7400 to $7180{ }^{14} \mathrm{C}$ years $\mathrm{BP}$ tongues of backbarrier deposits extended into the central basin during the transgression interfingering with the mudstone facies. This is the partly preserved inner edge of the estuarine 'sand plug' that forms at the mouth of wave-dominated estuaries fed by marine-derived sand (Dalrymple et al., 1992), also documented in Antony et al. (1996). A large part of the mudstone and shell layers facies was removed by erosion at the bottom of the main estuarine channel or tidal inlet between ca. 7000 and $6000{ }^{14} \mathrm{C}$ years BP forming a tidal ravinement surface.

\subsection{Sand facies (flood tidal delta and channel or inlet in Guadalete, tidal sand bar in Odiel-Tinto)}

This facies consists of medium light-grey sand grading upwards to fine sand, forming a volumetrically large lithosome that extends for long distances in longitudinal profiles but wedge out in short distances in sections across the estuaries (Fig. 4). Unfortunately drilling did not preserve the original sedimentary structures necessary for hydrodynamic interpretations. Millimeter- to centimeter-thick layers of silt and silty clay occur interbedded: a particular $5-\mathrm{cm}$ thick mud layer near the base was traced in various cores (Fig. 4, depth: $20.7 \mathrm{~m}$ in PSM108, 21.6 $\mathrm{m}$ in PSM109, 24.8 in PSM105). The fossil content of the sand includes Ostrea sp., Cardium sp., Solen sp., Chamelea sp., Dentalium sp. and nassarids.

Taking into account the physiography of the Guadalete estuary and the relative locations of the available drill cores, we interpret the sand facies as the proximal backbarrier, most probably flood tidal deltas, colonised by benthic molluscs. Sand layers record a concurrence of tides, seasonal changes in river input, and storm overwash, whereas the intervening mudstone layers settled from suspension during quiet episodes. The top of this lithosome is rather flat in a section across the valley, but scoured in an axial section. We interpret it as the bottom of the tidal inlet and place tentatively the maximum flooding surface at the flat non-eroded top of the sand body (Fig. 4).

Considering the morphology of the Odiel-Tinto estuary, we interpret these facies as sand shoals in the estuarine channel, colonised by Ostrea sp. that occur nowadays as interbedded layers. Radiocarbon dating indicates reworking of fossils because the older samples occur above the younger (e.g., Fig. 5).

\subsection{Sand facies of Odiel-Tinto (tidal meanders)}

Sand facies of Odiel-Tinto (tidal meanders) consist of layers of sand, one to several meters thick, which fine upwards and change into grey mudstone (Fig. 5). The erosional lower boundary is overlain by the coarser grain sizes available and large mechanically accumulated shells of Cardium sp., Ostrea sp., other ostreids, and gastropods that we interpret as a lag at the base of a channel fill. Radiometric ages suggest reworking and mixing of shells in the channels. Large Cardium are common towards the top of the sandy intervals, together with some Chamelea, rissoids, and wood fragments. We interpret these facies as parts of the transgressive (TST) and highstand (HST) systems tracts.

\subsection{Heterolithic facies}

The upper part of the cores consists of finely interlayered grey mudstone and light-grey, parallellaminated fine sand. An overall fining upward grain-size trend is usually recognised, and locally repeated several times vertically. In some cores, meter-thick layers of fine sand occur interbedded. Fossils, particularly gastropods and Cardium sp., abound; locally, wood fragments also occur. Moving upward, the fossil content shows a drastic reduction of miliolids, the absence of echinoderm fragments, and an increase of the percentages of the benthic foraminifers $H$. germanica and $E$. excavatum living in the restricted tidal flat environments (Fig. 4, depth interval 10 to $5 \mathrm{~m}$ ). Towards the top, at approximately $-9 \mathrm{~m}$, an interval with higher percentages of miliolids and lower contents of $H$. germanica and $E$. excavatum suggests more open marine conditions that may be related to an external influence at ca. $5445 \pm 105{ }^{14} \mathrm{C}$ years BP (Table 1$)$.

The topmost part of the heterolithic facies is burrowed brown clay with scarce fossils. Small lenticular crystals of gypsum, more frequent upwards, indicate environmental restriction, but it was 
not possible to carry out isotope analysis due to the absence of $A$. beccarii. These facies record the last phases of the vertical growth of sand bars and tidal flats where daily subaerial exposure caused restricted living conditions and highly fluctuating physical and chemical parameters.

We interpret these facies association as vertically accreted tidal sand bars and sand flats fed mainly by fluvial-derived sediment, although we did not recognise cyclic patterns similar to those usually found in tidally influenced settings.

The heterolithic facies also include bodies of fine grey sand with thin layers of mud (ca. 7.5 to $3.5 \mathrm{~m}$ in core PSM101, and ca. 9 to $6.5 \mathrm{~m}$ in core PSM106, Fig. 4). The scarce fossil content (Ostrea sp., Cardium sp., Solen sp., Chamelea sp., Dentalium sp., nassarids) concentrates toward the top. We interpret these bodies as the meandering tidal channels of the lower intertidal flat.

A particularly large sand body drilled between 8 and $2 \mathrm{~m}$ in PSM105 can be divided in two parts: The lower half is a fining upwards sequence recorded in the increasing number of fine-grained layers, very similar to a tidal flat with Cardium sp., very often fragmented, and plant remains. In contrast, the fine sand with scattered mollusc shells and other skeletal particles of the upper half is interpreted as a channel fill. Thus, the multi-storey sand body records repeated incision and filling of meandering tidal channels in the last $500{ }^{14} \mathrm{C}$ years BP (Fig. 4 and Table 1).

\subsection{Prograding estuarine barrier facies}

The prograding estuarine barrier facies are made up of medium sand with plenty of skeletal particles being accumulated nowadays. Beach ridges are covered by aeolian foredunes partly vegetated (Figs. 2 and 3 ).

\section{Palaeogeographical interpretation and discus- sion (Figs. 6 and 7)}

Subsurface data added to archaeological and historical evidences and interpretation of air photographs supply a number of deductions that can be related to the chronology of events of progradation $\left(\mathrm{H}_{1}\right.$ to $\left.\mathrm{H}_{4}\right)$ in the area.

The Late Pleistocene facies overlie marine Late Neogene (Plio-Pleistocene?) blue marlstones; this means that if there were older Pleistocene deposits in the estuary they have been removed by erosion.

The sea level reached elevations close to or above the present in the Spanish littorals during only the highstands of the Last (IS 5) and the Present (IS 1) Interglacials (Zazo et al., 1993). Fossil beach deposits witness at least two highstands during the IS 5 in the Gulf of Cadiz. Raised marine terraces occur consistently along the littoral of the Cadiz province and have been dated using $\mathrm{Th} / \mathrm{U}$ as deposited during the highstands $5 \mathrm{e}(128 \mathrm{ka})$ and $5 \mathrm{c}(95 \mathrm{ka})$. As they bear a warm fauna and occur at very similar topographic elevations, Zazo et al. (1997a) deduced that the sea reached almost the same level in both highstands, regardless of any tectonic influence. In contrast, only one probable evidence of a sea level highstand of IS 5 age has been found so far in the littoral of Huelva, namely, in the El Asperillo cliffs between the estuaries of Odiel-Tinto and Guadalquivir. Although the lack of faunal content barred any direct dating in this outcrop, Zazo et al. (1997b) proposed an IS 5 age (s.1.) on the basis of stratigraphy and dating of the limiting deposits.

The oldest Late Pleistocene rocks recovered in the drill cores are fluvial deposits dated as ca. 30 to 25 $\mathrm{ka}$ in the Odiel estuary (Table 1 and Fig. 4), although the fluvial sedimentation extended to more recent times. The fluvial lithosome accumulated during the IS 3 in a highstand phase that did not reach the topographic elevation of the present. During IS 3 , ca. 30,000 years BP, a humid period recognised in the littorals of Mallorca (Goy et al., 1997), Canary Islands (Hillaire-Marcel et al., 1995), and North Africa (Zouari et al., 1998) favoured an increase of the surface occupied by lakes, the superficial runoff, and the generation of layers rich in organic matter interbedded with aeolian dunes in El Asperillo (Zazo et al., 1997a,b).

The fourth-order eustatic cycle responsible for the present depositional sequence began with the fall of sea level after the ISS 5e and includes several smaller fifth-order cycles, one of which corresponds to the fluvial unit. Somoza et al. (1997) nicely depicted these cycles in the Gulf of Cadiz, recognising four 

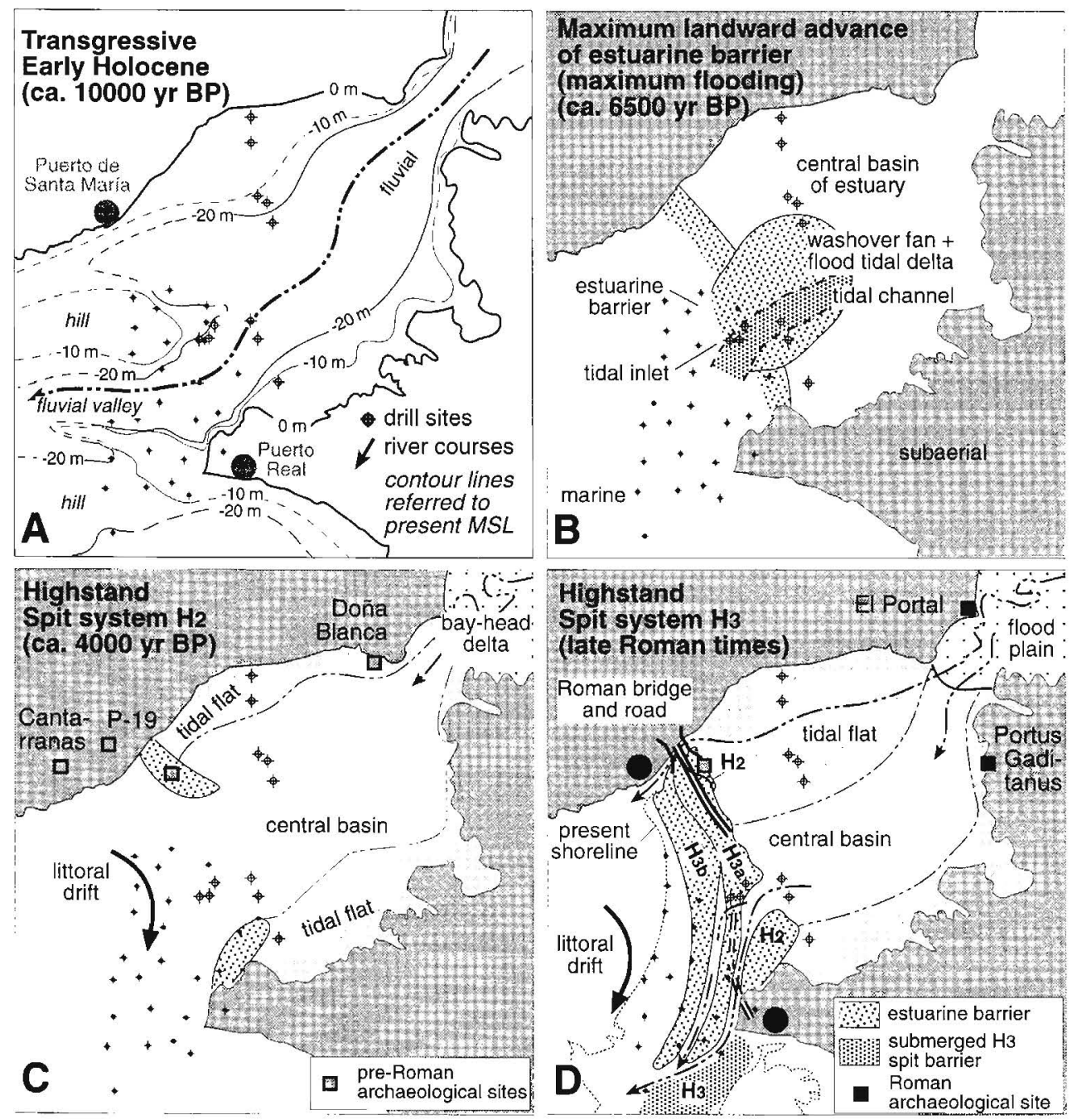

Fig. 6. Four palaeogeographical steps of the changing landscapes in the Guadalete incised-valley. A part of the data come from geotechnical drill cores and maps by INTECSA (Internacional de Ingeniería y Estudios Técnicos SA).

successive highstands at ca. 105-95 ka (ISS 5c), 85-80 ka (ISS 5a), 60-50 ka (IS 4), and 30-25 ka (IS 3), the last one closely matching the age of the fluvial lithosome in the studied estuaries. The curve is very similar to other curves corrected with global oxygen isotopes (Skene et al., 1998) although the age that they propose for the IS 3 highstand is slightly older. Thus we correlate it with the younger highstand of the seismic unit 10 distinguished by Somoza et al. (1997). The fluvial unit also correlates with the upper regressive sequence of the Late Pleistocene Unit Q7 defined in the Gulf of

Fig. 7. Four palaeogeographical steps of the changing landscapes in the Guadalete incised-valley. Partly constructed with data from drill cores and data from Cimentaciones Especiales, GEOCISA (Geotecnia y Cimientos SA), and Laboratorio de Análisis Industriales VORSEVI 

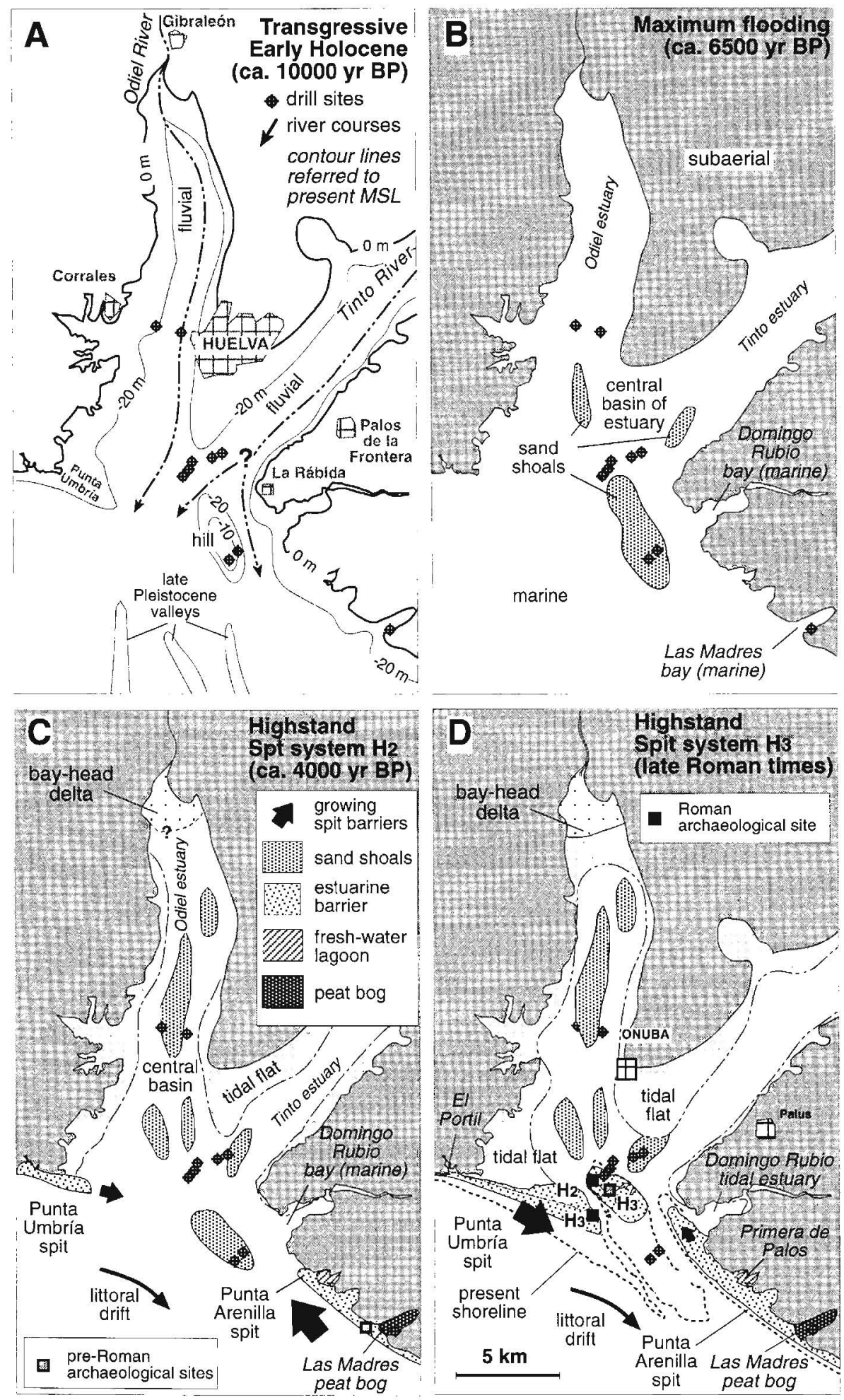
Cadiz continental shelf by Rodero et al. (1999) to include deltaic and littoral facies accumulated in the middle shelf during a tectonically stable phase.

The Odiel, Tinto and Guadalete Rivers excavated incised-valleys during the fall of sea level at ca. 18 $\mathrm{ka}$. This was the time of maximum ice volume and the greater part of the continental shelf of southern Spain was exposed to subaerial conditions and erosion. Vanney and Menanteau (1985) recognised remains of these palaeo-relieves. At that time, the coastline was placed some $13-14 \mathrm{~km}$ towards the south and southwest from its present position, and the sea level some 120 below present MSL (Hernández-Molina et al., 1994).

The erosional surface cut by rivers during the glacial lowstand is a subaerial unconformity that can be described as the type- 1 sequence boundary (cf., van Wagoner et al., 1988) of the fifth-order cycle. As no fluvial deposits associated to the lowstand (the marine correlative conformable deposits of Posamentier et al., 1988) could be positively identified in the study area, this surface coincides with the transgressive surface. However, the chronological meaning of the ravinement surface of the incised-valley and its usage as a boundary for stratigraphic units is more complex (cf., Catuneanu et al., 1998).

In the Odiel-Tinto estuary the erosional sequence boundary cuts irregularly the conglomeratic Pleistocene deposits (Fig. 5). Some palaeo-relieves are big enough to form (palaeo) hills. One of these is buried under the present Saltés Island, and partly blocked the entrance to the estuary during the transgression contributing to form a shoal as early as the maximum flooding (Fig. 7). This 'central' palaeo-relief interfered with the combined effects of waves and tidal currents conditioning the early accumulation of sand bars at the estuary mouth. The distribution of facies in the logs suggests an offlapping pattern and the progradation of the landward sides of the bars into the muddy central basin (Fig. 5).

At the beginning of the Holocene and the Flandrian transgression (ca. 10,000 BP) the sea level was at $-30 /-35 \mathrm{~m}$ in the Portuguese (Dias et al., 1997) and Spanish (Hernández-Molina et al., 1994) continental shelves. The postglacial rise of sea level was discontinuous with repeated rapid rises each followed by stillstands or at least very slow rates of rise that created little accommodation, giving the overall image of a jumpy rise, as recognised in many other localities (e.g., Hernández-Molina et al., 1994; Bellotti et al., 1995; Somoza et al., 1997, 1998). Such similarities may contribute to the dreamed global curve of Stanley (1995).

The trend of sea level rise accelerated between 16 and $12 \mathrm{ka}$ in the Portuguese shelf with rates of 15 $\mathrm{m} / \mathrm{ka}$ (Dias et al., 1997). Data from aeolian dunes and palaeosoils in the Spanish coast of the Gulf of Cadiz (Huelva) suggest an acceleration of the sea level rise between 14 and $10.5 \mathrm{ka}$ (Zazo et al., 1997b). In the upper continental slope off our study area this event coincides with the accumulation of sandy contourite layers by the Mediterranean outflowing waters in the Bølling-Allerød (14-11 ka) climatic optimum. The deglaciation trend was broken during the Younger Dryas (11-10 ka) but started again immediately after this episode (Sierro et al., 1999).

The bulk of estuarine deposition in the studied incised-valleys corresponds to both the TST and HST of the present fourth-order cycle, and the succession of facies (Figs. 4 and 5) closely matches the vertical sequences found in other wave- and mixed tide- and wave-dominated estuaries (cf., Dalrymple et al., 1992, 1994; Roy, 1994; Zaitlin et al., 1994).

The oldest record of the Holocene transgression (Flandrian) is the thin fluvial and marine facies that occurs above the sequence boundary in the deepest part, topographically lowest $(-30 \mathrm{~m})$, part of the drilled Guadalete incised-valley (Figs. 4 and 6). The topographic position and dating of the overlaying sediments (except the peat layers) suggest ages around $10,000 \mathrm{BP}$. This means that the transgressive shoreline had proceeded to a position close to the present central estuarine basins, and witness the retreat towards land of the fluvial-marine interface. Their upper boundary marks the initial flooding surface. The transgressive deposits are poorly developed as compared with the thick tide-dominated fluvial deposits found in other transgressed estuarine channels (e.g., Richards, 1994) and that may explain that they were not recognised and described in previous papers studying this area. This may be an effect of the small accommodation space owing to the high topographic elevation of the thalweg relative to the highstand, but space constraints may lead to considerably complex facies architectures. The importance 
of fluvial input is also dependent on the geometry of the bedrock valley (Cooper, 1993) which in part is controlled by the geological framework (Dabrio et al., 1995; Riggs et al., 1995).

It is important to remark that the Holocene filling of estuaries does not begin with fluvial conglomerates as suggested by Borrego et al. (1997), because these deposits are of Late Pleistocene age (Fig. 5 and Table 1), and were incised by rivers producing the erosional surface of the sequence boundary.

The faunal content of the lower part of the muddy central basin facies indicates restricted living conditions that must be related to the first stages of drowning of the valleys ca. $8500 \mathrm{BP}$. At that time, the fresh/salt water limit was placed seaward of the study area due to the high input of fresh water caused by the vicinity of the river mouth. Benthic communities evidence the reduced salinity, whereas the abundant plant debris suggests that the lower reaches of the river were somewhat swampy. Thus, the muddy central-basin facies of the TST record conditions of increasing salinity during the landward shift of the boundary between fresh and marine waters as the sea level rose and the transgression proceeded far beyond inland of the drilled areas. The gradual change to more open marine conditions allowed more varied, richer faunas in the upper part of the mudstone facies.

A further proof of the landward retreat of the coast related to the late stages of sea level rise is the coarsening upwards trend found in Guadalete estuary, that reveals the retrogradation of the estuarine barrier and its accompanying rim of backbarrier deposits (washover fans, flood tidal delta and tidal inlet) towards the fine-grained central basin during $\mathrm{H}_{1}$ times. However, the preservation of these deposits was greatly compromised by the shifting tidal inlet that also moved into the estuary. Eventually it destroyed a part of the backbarrier units producing ravinement surface that locally reached a depth of 13 m (Fig. 4).

Ca. 6500 years BP maximum flooding occurred in the central basin. This is supported by the increased percentages of miliolids and echinoderm fragments and decreased numbers of the benthic foraminifers $H$. germanica and E. excavatum. This period coincides with the maximum landward migration of the estuarine barrier in Guadalete. Most of the input of fluvial sediment was trapped in the bayhead deltas and the axial zones of both the studied incised-valleys, similarly as documented by Nichol et al. (1997).

The HST includes muddy and clayey (central basin), and heterolithic (tidal sand bars and sand flats, tidal meanders) facies. The vertical sequence shows a two-fold grain size trend. Coarsening in the lower part records the arrival to the central basin of the distal bayhead delta sediments whereas fining upward to the top records the ongoing transformation into intertidal to supratidal flats and, eventually, into a river-dominated flood plain. Nichol et al. (1997) found that a $3-8 \mathrm{~m}$ thick bed of interbedded muddy central basin and sandy river flood deposits formed during the present early highstand $(6.5$ to $3 \mathrm{ka})$ in association with maximum flooding surfaces. Then began the progradation of sandy distributary mouthbar deposits. Following this scheme, the interbedded channel-shaped sand bodies of variable thickness and marine to estuarine faunas in the long, funnel-shaped Odiel estuary must represent subtidal and intertidal meandering channels.

A large part of the estuarine fill is of $\mathrm{H}_{1}$ age (ca. $6554-4400{ }^{14} \mathrm{C}$ years $\mathrm{BP}$ ). In this time the rate of fluvial input to estuaries surpassed the rate of sea level rise promoting vertical accretion in the estuarine basin (Figs. 4 and 5) and the first emergence of tidal flats bordering the estuaries. Thus, the subaerial expression is very reduced except for the initial bayhead delta and the rims of tidal flats (Figs. 6 and 7). We assume that increased vertical accretion requires stable estuarine barriers separating the quiet basins from the rougher open-sea waters. Spits grew during $\mathrm{H}_{1}$ times in spite of the trapping of sediment in the estuaries, because the littoral drift was largely fed by erosion of sandy Plio-Pleistocene outcrops along the coast, that were cut into cliffs. Some of these cliffs were probably inherited from earlier highstands and experienced renewed erosion. Large stretches of the cliffs are nowadays separated from the sea by sandy coastal plains and supply little sediment to the coastal budget.

Despite the former reasoning, no subaerial parts of the $\mathrm{H}_{1}$ estuarine barriers have been recognised so far in the coastal areas of the Gulf of Cadiz. However, the study of the Las Madres peat bog located close to the entrance of the Odiel-Tinto estuary (Fig. 7) supplied very interesting but indirect evidences of 
spit and beach ridge accumulations at that time (Zazo et al., 1996b). The little Las Madres incisedvalley was flooded during the postglacial rise of sea level forming a small marine embayment (Fig. 7). Shortly after the maximum sea level rise, the bay was isolated from the sea by a beach barrier and transformed into a lagoon ca. $5480 \pm 60{ }^{14} \mathrm{C}$ years BP (Table 1), with high contents of Chenopodiaceae and Isoetaceae pollen that indicate humid and brackish environments between 5500 and ca. 4000 years BP. Most probably, a large part of the Las Madres beach barrier has been eroded by recent littoral drift but its remains are largely covered by aeolian dunes and we could not observe $\mathrm{H}_{1}$ deposits, despite intense digging. Zazo et al. (1996b) supposed that the Punta Arenilla spit was the prolongation of the Las Madres beach barrier, and concluded that it was the first spit to grow in the Odiel-Tinto estuary mouth.

The absence of preserved subaerial deposits of $\mathrm{H}_{1}$ age is due to the concurrence of reduced input of fluvial sands to the bay mouth in times shortly after the maximum transgression, strong tidal influence associated to large tidal prisms, and later erosion by laterally shifting tidal inlets and coastal drift. Therefore, the only remains of $\mathrm{H}_{1}$ estuarine barriers should occur at the base of the sequences, close to the thalweg of the incised-valley, and it is most unlikely that $\mathrm{H}_{1}$ deposits will ever be found in the emergent parts of spit barriers. We have found shells of $\mathrm{H}_{1}$ age in cores and at the surface, but they are reworked and incorporated into younger units.

At $5445 \pm 105{ }^{14} \mathrm{C}$ years BP an external influence promoted open marine conditions in a restricted tidal flat sequence in Guadalete (a layer placed at $-9 \mathrm{~m}$ in Guadalete, PSM-104). This may be the response to a minor rise of sea level that should leave coastal deposits above present sea level, something not yet unambiguously documented in our study area. The only reference to an anomalous sea level of this age is a layer at $+1 \mathrm{~m}$, dated between 5900 and 4000 ${ }^{14} \mathrm{C}$ years BP in Tunisia (Jedoui et al., 1998) and interpreted as the result of the postglacial hydro-isostatic rebound predicted by rheological models of continental margins. If this is the case, we have found the first evidence of such a phenomenon in the southern Iberia Peninsula.

Major changes of landscape occurred in the estuaries during the time of $\mathrm{H}_{2}$ spit unit deposition $\left(4200-2550{ }^{14} \mathrm{C}\right.$ years BP). At ca. 4000 years BP the Las Madres coastal lagoon was transformed into a peat bog with high content of Ciperaceae (Carex) pollen indicative of fresh water that persisted until 1000 years BP (Zazo et al., 1996b). The palynologic analysis of the peat bog also reveals a sudden change of vegetation to more arid conditions. Human settlements on $\mathrm{H}_{2}$ spit deposits recorded as lithic workshop levels dated as 4th to 2nd millennium BC (Gómez et al., 1993) give further evidence for the existence of an emergent barrier separating the peat bog from the open sea, and this may also indicate that the present Punta Arenilla spit was growing but at an embryonic stage. Pendón et al. (1998) also consider that the Punta Arenilla spit was beginning to grow and did not shelter the Domingo Rubio valley (a side branch of the Tinto estuary, Fig. 4) that at that ca. $3090{ }^{14} \mathrm{C}$ years $\mathrm{BP}$ acted as a tidedominated, open marine environment.

The occurrence of marine shells well inside the Odiel-Tinto estuary beyond the topographic constriction induced by pre-Holocene deposits (Figs. 5 and 7) proves that open estuarine conditions existed at least until ca. $3295 \pm 105{ }^{14} \mathrm{C}$ years BP.

There are human settlements of Bronze Age (1850-1650 BC, Gómez Ponce et al., 1997) on $\mathrm{H}_{2}$ spit deposits in Guadalete as well (Figs. 2 and 6). From the study of drill cores, we infer that in Guadalete there was a single river course probably to the north of the deepest part of the incised-valley (Fig. 6).

Sanlaville et al. (1997) have documented a phase of huge coastal progradation of Bronze Age (2nd millennium BC) in the Syrian coast, that they correlated with increased alluvial discharge mainly controlled by climatic oscillations. This phase lasted for a millennium.

Prominent changes of landscape accelerated around 2500 years BP (Lario et al., 1995; Goy et al., 1996; Zazo et al., 1996a,b; Borja et al., 1999) when spit unit $\mathrm{H}_{2}$ ceased to prograde and $\mathrm{H}_{3}(2300-800$ ${ }^{14} \mathrm{C}$ years $\mathrm{BP}$ ) began to grow supporting the oldest preserved foredune systems in the area (Borja, 1997; Borja et al., 1999). This is a period of increased rates of progradation at the estuarine barriers and of vertical aggradation in the estuaries of the AtlanticMediterranean linkage area, but also noted in other places (Nichol et al., 1997; Eisma, 1998). The di- 
achronism of the vertical change from intertidal to supratidal facies, observed in cross-sections of Guadalete (Fig. 4), evidences the centripetal progradation of the tidal flats (Figs. 6 and 7).

The study of morpho-sedimentary units and ${ }^{14} \mathrm{C}$ dating gives key information about their genesis. In Guadalete, two fluvial courses crossed the tidal flats. One flowed to the north (the present Guadalete River) whereas the other occupied a southern position (the present San Pedro River) roughly following the old incised-valley (Fig. 4). Both rivers supplied sediment to the active littoral drift that favoured the growth of a broad spit barrier since the early times of $\mathrm{H}_{3}$ development (post-2300 years BP). We infer that the main river was the one in the north (palaeoGuadalete) because it was able to feed a large spit that forced the lower reaches of the other river to bend southwards following a north-south course still preserved as a wide swale (Fig. 4). It seems likely that the palaeo-San Pedro River also experienced displacements to the west as suggested by the broad north-south oriented ridges and swales (Figs. 2 and 6). As pointed out by Willis (1997), changes in the relative rate of sediment supply and basin accommodation are important controls on the style of valley fill.

A Roman bridge and a partly preserved Roman way offered a safe passage between Puerto de Santa María and Puerto Real in 1st-2nd centuries $\mathrm{AD}$ (Gómez Ponce et al., 1997). The way crosses $\mathrm{H}_{2}$ and $\mathrm{H}_{3}$ deposits (Figs. 2 and 6) above tidal limits and storm surges, and proves the existence of emergent spit barriers at this time.

In Odiel-Tinto, the $\mathrm{H}_{2}$ and $\mathrm{H}_{3}$ phases are characterised by major progradation of the Punta Arenilla and Punta Umbría spits and the emergence of small parts of Saltés Island. The asymmetrical sedimentation pattern produced by the concurrence of littoral drift, refracted waves, and tidal currents favoured the opposite growth of the Punta Arenilla and Punta Umbría spits since the early stages of $\mathrm{H}_{2}$. Interpretation of air photographs shows that flood tidal currents tend to flow close to the eastern side of the estuary whereas ebb tides run closer to the western side, suggesting that Punta Umbría and Saltés tend to be independent.

This issue is important because of the genesis of the estuarine barrier based on the morphology of beach ridges and the proposed evolution of the Odiel-Tinto estuarine barrier during the HST has been the subject of diverse interpretation and heated controversy. Figueroa and Clemente (1979) supposed that the Punta Umbría spit and Saltés Island grew independently, whereas Rodríguez Vidal (1987) and Lario (1996) proposed that they formed a single body before ca. 2500 years BP when they were separated by a tidal inlet.

Pendón et al. (1998) recognised a wave-dominated period in Domingo Rubio channel that begun about 2500 years $\mathrm{BP}$, during which waves transported sediment into the inner estuary and also along the Punta Arenilla spit favouring rapid longitudinal growth toward the northwest, sheltering in the process the former bay and turning it into a more channel-shaped basin.

During $\mathrm{H}_{4}$ (last 500 years), the confluence of littoral drift, increased sediment input by rivers, additionally magnified by increasing aridity and deforestation favoured the big development of the $\mathrm{H}_{4}$ unit. A similar effect is recorded in the Tiber delta after $1500 \mathrm{AD}$, with an advancement of the shoreline of $9 \mathrm{~m} \mathrm{yr}^{-1}$. Many of these changes were triggered or accelerated by anthropic activities. The first effects on the Spanish continental shelf sedimentation date back mining in Roman times $\left(\mathrm{H}_{3}\right)$ (Maldonado and Nelson, 1999; Nelson et al., 1999) but van Geen et al. (1997) showed that the impact increased dramatically in the last 120 years $\left(\mathrm{H}_{4}\right)$.

The barred, almost filled estuaries allowed the dominance of tidal action that helped to the rapid silting of the sheltered basins, as illustrated by Pendon et al. (1998) in Domingo Rubio.

The historical record of topographic maps in Guadalete estuary indicate that most of unit 4 has been deposited in the last 300 years. For this reason, the washover fans caused by the 1755 tsunami of the Lisbon earthquake broke the spit at a distance of over $1 \mathrm{~km}$ from the present coast (Dabrio et al., 1998). The present rates of progradation are very low and many beaches undergo erosion because of trapping of sediment into the many dams built in the last 60 years, aggravated in many places by misplaced coastal works. The study of the balance between reduced water and sediment supply vs. sea level rise is still in need of much corporate study, but an enhancement of the "natural' processes (river flood- 
ing and so on) may help to reduce its effects (Sánchez-Arcilla and Smith, 1998).

The upwards increasing restriction on conditions of life recorded in the TST and HST results from the vertical aggradation of sediments and the rise of the estuary floor that progressively approaches the MSL, changing from subtidal to inter and supratidal. An additional result of the infill process and the reduction of the accommodation space is that the interchange of waters with the open sea is progressively reduced, magnifying the relative importance of the input of fluvial waters to the tidal flats, and also the tidal influence on sediment transport. Assemblages of highly tolerant euryhaline benthic foraminifers shift accordingly to match the ever-changing conditions: A. beccarii, $H$. germanica, and $E$. excavatum are the most abundant taxa in the proximal, inner estuarine areas, while miliolids are only abundant in the more distal regions, towards the nearshore, where they are joined by echinoderms. The reduced number of taxa contrasts with the high number of individuals, owing to reduced competition and predation, and high nutrient concentration.

The filling follows a two-fold pattern due to the change from vertical accretion to lateral (centripetal) progradation, that may give the impression of an acceleration of the sedimentation rates. In a first stage, subaqueous sedimentation greatly reduces water depth and the accommodation space, but that does not have an appreciable effect in the surface morphology, except near the bayhead delta. In the second stage there are rapid geographical changes and landscape modifications, when the surface occupied by the flooded estuary diminishes rapidly due to fast expansion of the emergent areas. The decreasing tidal prism plays a key role in this stage. Many other estuaries of the Atlantic-Mediterranean linkage area experienced a similar evolution with rapid coastal advances during $\mathrm{H}_{4}$ that, in some cases (Lario et al., 1995), amounted to $3 \mathrm{~m} \mathrm{yr}^{-1}$.

The two-fold evolution has major implications when constructing curves of subsidence rate using radiocarbon dates. A reliable curve can only be drawn with the radiocarbon data of the samples collected along a particular drill core. Comparison of the various curves obtained in an estuary will give a "mean" curve of subsidence where any details may be blurred by the various behaviours of sedimenta- tion. Mixing data obtained from samples collected all through the estuary and its associated tidal flats in a single curve is likely to produce most inaccurate values of sedimentation rates.

We have calculated rates of sea level rise in the central estuarine basin of the Guadalete estuary using data from core PSM104 (Fig. 4). Between 10,000 and 6500 years BP the mean rate was $5.7 \mathrm{~mm} \mathrm{yr}^{-1}$, whereas between 6500 and 4000 years BP it was reduced to only $2.6 \mathrm{~mm} \mathrm{yr}^{-1}$.

\section{Conclusions}

Cross-sections established from continuous coring of the studied estuaries allowed to offer the first comprehensive sedimentary interpretation of the estuarine fill of the incised-valleys created along the present coast of the Gulf of Cadiz during the last glacial fall of sea level.

The studied estuaries record repeated incision during falls of sea level with preserved deposition during at least two highstands of Late Pleistocene (IS 3) and Holocene ages. The overall pattern has been correlated for the first time with the fourth-order eustatic oscillations and the superimposed fifth-order cycles recorded in depositional sequences found in the shelf off the study area (Somoza et al., 1997; Nelson et al., 1999; Rodero et al., 1999).

A fluvial lithosome accumulated during IS 3 in a highstand phase that did not reach the topographic elevation of the Present, and coincided with a humid period recognised in many places around the study area.

According to data from the shelf (HernándezMolina et al., 1994), at the beginning of the Holocene and the Flandrian transgression (ca. 10,000 years $\mathrm{BP}$ ) the sea level in the Gulf of Cadiz was $30-35 \mathrm{~m}$ below present MSL. The first marine evidence of the Holocene (Flandrian) transgression in the studied estuaries occurs $30 \mathrm{~m}$ below present MSL in Guadalete and 22 to $30 \mathrm{~m}$ below present MSL in Odiel-Tinto incised-valleys. These differences reflect topographic irregularities along the thalweg of rivers.

The maximum flooding occurred at ca. 6500 years $\mathrm{BP}$, coinciding with the maximum landward migration of the estuarine barrier in the Guadalete. Most of 
the input of fluvial sediment was trapped in the bayhead deltas and the axial zones of the estuaries.

After 6500 years BP the evolution of the estuarine filling is closely related to the decrease of the rate of sea level rise from $5.7 \mathrm{~mm} \mathrm{yr}^{-1}$ between 10,000 and 6500 years $\mathrm{BP}$, to $2.6 \mathrm{~mm} \mathrm{yr}^{-1}$ between 6500 and 4000 years BP recorded in the central estuarine basin. The rate of fluvial input to estuaries surpassed the rate of sea level rise (i.e., creation of accommodation), favouring the vertical accretion of tidal flats and the accumulation of the spit unit $\mathrm{H}_{2}$ colonised by human settlements (Borja et al., 1999). Vegetation changed to more arid conditions. The increase in vertical accretion caused a reduction of the tidal prisms in the estuaries that allowed the accumulation of stable spit barriers and the apparent effect of waves was magnified, particularly between 2500 and 2700 years $\mathrm{BP}$, when the spit unit $\mathrm{H}_{3}$ began to grow and the first associated aeolian foredune systems accumulated. In Guadalete, two fluvial courses supplied sediment to the active littoral drift and favoured the growth of a broad $\mathrm{H}_{3}$ spit barrier crossed by a Roman way.

In the last 500 years, the confluence of littoral drift, large fluvial input magnified by deforestation, and increasing aridity favoured the accumulation of the large $\mathrm{H}_{4}$ spit unit. Historical data, particularly the present position of watch towers built in the 17th century $\mathrm{AD}$, evidence rapid coastal progradation rates up to $3 \mathrm{~m} \mathrm{yr}^{-1}$ (Lario et al., 1995).

The filling follows a two-fold pattern due to the progressive change from vertical accretion to lateral (centripetal) progradation. First, subaqueous sedimentation greatly reduces water depth and the accommodation space, but that does not have an appreciable effect in the surface morphology, except near the bayhead delta. Then, the surface occupied by the flooded estuary diminishes rapidly due to fast expansion of the emergent areas, producing rapid geographical changes and landscape modifications. A main derivation is that reliable curves of subsidence rate can be obtained using only the radiocarbon data and depths for a single drill core. A single curve reflects sedimentation in a particular spot of the estuary. Comparison of the various curves obtained in an estuary will give a "mean" curve of subsidence.

\section{Acknowledgements}

Financial support from the Commission of the European Communities, Directorate General for Science, Research and Development (DG XII), Environment Programme, as a part of the project 'Climate Change and Coastal Evolution in Europe' (EV5VCT94-0445), F. Areces Project "Cambios climáticos y nivel del mar..." (1997-2000), and by Spanish DGICYT Projects PB95-0109 and PB95-0946. INTECSA (Internacional de Ingeniería y Estudios Técnicos SA), Cimentaciones Especiales, GEOCISA (Geotecnia y Cimientos SA), and Laboratorio de Análisis Industriales VORSEVI kindly released many drill logs and are gratefully acknowledged. We are indebted to Dr. A. Maldonado and an anonymous referee who carefully reviewed the manuscript giving invaluable suggestions that greatly improved the paper.

\section{References}

Allen, G., 1991. Sedimentary processes and facies in the Gironde estuary: a recent model of mesotidal estuarine systems. In: Smith, D.G., Reinson, G.E., Zaitlin, B.A., Rahmani, R.A. (Eds.) Clastic Tidal Sedimentology. Can. Soc. Pet. Geol. Mem. 16, 29-39.

Allen, G.P., Posamentier, H.W., 1993. Sequence stratigraphy and facies model of an incised valley fill: the Gironde estuary, France. J. Sediment. Petrol. 63, 378-391.

Allen, G.P., Posamentier, H.W., 1994. Transgressive facies and sequence architecture in mixed tide- and wave-dominated incised valleys: example from the Gironde estuary, France. In: Dalrymple, R.W., Boyd, R., Zaitlin, B.A. (Eds.), Incised-Valley Systems: Origin and Sedimentary Sequences. Soc. Econ. Paleontol. Mineral., Spec. Publ. 51, 225-240.

Antony, E.J., Lang, J., Oyede, L.M., 1996. Sedimentation in a tropical, microtidal, wave-dominated coastal-plain estuary. Sedimentology 43, 665-675.

Bellotti, P., Milli, S., Tortora, P., Valeri, P., 1995. Physical stratigraphy and sedimentology of the Late Pleistocene-Holocene Tiber delta depositional sequence. Sedimentology 42, $617-634$.

Borja, F., 1997. Dunas litorales de Huelva (SW de España) Tipología y secuencias Pleistoceno Superior-Holoceno. In: Rodríguez-Vidal, J. (Ed.), Cuaternario Ibérico. Universidad de Huelva, 84-97.

Borja, F., Zazo, C., Dabrio, C.J., Díaz del Olmo, F., Goy, J.L., Lario, J., 1999. Holocene aeolian phases and human settlements along the Atlantic coast of southem Spain. The Holocene 9, 337-339. 
Borrego, J., 1992. Sedimentología del Estuario del Río Odiel, Huelva, SW España. PhD Thesis. University of Sevilla, 308 pp.

Borrego, J., Morales, J.A., Pendón, J.G., 1993. Holocene filling of an estuarine lagoon along the mesotidal Coast of Huelva: the Piedras River mouth, southwestern Spain. J. Coastal Res. 8, $321-343$.

Borrego, J., Morales, J.A. Pendón, J.G., 1997. Evolución holocena de la cuenca central del estuario del Río Odiel (Golfo de Cádiz, España). Abstract Volume 2nd Symposium on the Atlantic Iberian Continental Margin, 143-144.

Catuneanu, O., Willis, A.J., Mall, A.D., 1998. Temporal significance of sequence boundaries. Sediment. Geol. 121, 157-178.

Chiocci, F.L., Ercilla, G., Torres, J., 1997. Stratal architecture of Western Mediterranean Margins as the result of the stacking of Quatemary lowstand deposits below glacio-eustatic fluctuation base-level. Sediment. Geol. 112, 195-217.

Cooper, J.A.G., 1993. Sedimentation in a river dominated estuary. Sedimentology 40, 979-1017.

Dabrio, C.J., Polo, M.D., 1987. Holocene sea-level changes, coastal dynamics and human impacts in southern Iberian Peninsula. In: Zazo, C. (Ed.), Late Quaternary Sea-Level Changes in Spain. Museo Nal. Ciencias Naturales, CSIC 10, $227-247$.

Dabrio, C.J., Goy, J.L., Lario, J., Zazo, C., Borja, F., González, A., 1995. The Guadalete estuary during the Holocene times (Bay of Cadiz, Spain. Int. Union Quat. Res., Subcommis. Mediterr. Black Sea Shorelines Newslett. 17, 19-22.

Dabrio, C.J., Goy, J.L., Zazo, C., 1998. The record of the tsunami produced by the 1755 Lisbon earthquake in Valdelagrana spit (Gulf of Cadiz, southern Spain). Geogaceta 23, 31-34.

Dabrio, C.J., Zazo, C., Lario, J., Goy, J.L., Sierro, F.J., Borja, F., González, J.A., Flores, J.A., Sequence stratigraphy of Holocene incised-valley fills and coastal evolution in the Gulf of Cadiz (southern Spain). Geol. Mijnbouw, in press.

Dalrymple, R.W., Zaitlin, B.A., Boyd, R., 1992. Estuarine facies models: conceptual basis and stratigraphic implications. J. Sediment. Petrol. 62, 1130-1146.

Dalrymple, R.W., Boyd, R., Zaitlin, B.A., 1994. History of research, types and internal organization of incised-valley systems: introduction to the volume. In: Dalrymple, R.W., Boyd, R., Zaitlin, B.A. (Eds.), Incised-Valley Systems: Origin and Sedimentary Sequences. Soc. Econ. Paleontol. Mineral., Spec. Publ. 51, 3-10.

Dias, J.M.A., Rodrigues, Magalhäes, F., 1997. Evolução da linha de costa, em Portugal, desde o Último Máximo Glaciário até à actualidade: sintese dos conhecimentos. Est. Quat. AEPQ Lisboa $1,53-66$.

Eisma, D., 1998. Intertidal Deposits. River Mouths, Tidal Flats, and Coastal Lagoons. CRC Press, Boca Raton, FL, USA, 525 pp.

Figueroa, M.E., Clemente, L., 1979. Dinámica geomorfologica del Estuario de los ríos Tinto y Odiel (Huelva). Aplicación a la ordenación del territorio. IV Reunión Nacional para el Estudio del Cuaternario, Bañolas, 2 pp.

Gómez, F., Castiñeira, J., Campos, J.M., Borja, F., García, J.M. 1993. Prospección arqueológica superficial. Interfluvio Guadi-
ana-Piedras. Anuario Arqueológico de Andalucia, 1991, Junta de Andalucía, Sevilla, II, 239-246.

Gómez Ponce, C., Borja, F., Lagostena, L.., López Amador, J.J., Ruiz, J.A., Borja, C., 1997. Primeras fases de la evolución de la flecha litoral de Valdelagrana (El Puerto de Santa María, Cádiz). Datos arqueológicos. In: Rodríguez-Vidal, J. (Ed.), Cuaternario Ibérico. Universidad de Huelva, 165-167.

Goy, J.L., Zazo, C., Dabrio, C.J., Lario, J., Borja, F., Sierro, F.J., Flores, J.A., 1996. Global and regional factors controlling changes of coastlines in southern Iberia (Spain) during the Holocene. Quat. Sci. Rev. 15, 773-780.

Goy, J.L., Zazo, C., Cuerda, J., 1997. Evolución de la áreas marginolitorales de la costa de Mallorca (Islas Baleares) durante el Último y Presente Interglacial: nivel del mar Holoceno y clima. Bol. Geol. Min. 108, 455-463.

Goy, J.L., Zazo, C., Dabrio, C.J., Baena, J., Harvey, A.M., Silva, P., Gonzalez, F., Lario, J., 1998. Sea level and climate changes in the Cabo de Gata Lagoon (Almería) during the last $6500 \mathrm{yr}$ BP. Int. Union Quat. Res., Subcommis. Mediterr. Black Sea Shorelines Newslett. 20, 11-18.

Gutiérrez-Más, J.M., Domínguez-Bella, S., López-Aguayo, F., 1994. Present-day sedimentation patterns on the Gulf of Cadiz northem shelf from heavy mineral analysis. Geo-Mar. Lett. 14, $52-58$.

Hernández-Molina, F.J., Somoza, L., Rey, J., Pomar, L., 1994. Late Pleistocene-Holocene sediments on the Spanish continental shelves: a model for very high-resolution sequence stratigraphy. Mar. Geol. 120, 129-174.

Hillaire-Marcel, C., Ghaleb, B., Gariépy, C., Zazo, C., Goy, J.L., Hoyos, M., 1995. U-series dating by TIMS technique of land snails from paleosols in the Canary Islands. Quat. Res. 44, 276-282.

Jedoui, Y., Kallel, N., Fontugne, M., Ben Ismail, H., M'Rabet, A., Montacer, M., 1998. A high relative sea-level stand in the Middle Holocene of southeastem Tunisia. Mar. Geol. 147, $123-130$.

Lario, J., 1996. Último y Presente Interglacial en el área de conexión Atlántico-Mediterráneo (Sur de España). Variaciones del nivel del mar, paleoclima y paleoambientes. PhD Thesis. University Complutense and CSIC, Madrid, 269 pp.

Lario, J., Zazo, C., Dabrio, C.J., Somoza, L., Goy, JL., Bardají, T., Silva, P.G., 1995. Record of recent Holocene sediment input on spit bars and deltas of south Spain. J. Coastal Res., Spec. Issue 17, $241-245$.

Maldonado, A., Nelson, C.H., 1999. Interaction of tectonic and depositional processes that control the evolution of the Iberian Gulf of Cadiz margin. Mar. Geol. 155, 217-242.

Menanteau, L., 1979. Les marismes du Guadalquivir. Example de transformation d'un paysage alluvial au cours du Quaternaire récent. These 3 eme cycle, Universite Paris Sorbonne, 154 pp.

Mitchum, R.M., Jr., Vail, P.R., Thompson, S., III, 1977. Seismic stratigraphy and global changes of sea level: Part 2. The depositional sequence as a basic unit for stratigraphic analysis. In: Payton, C.E. (Ed.), Seismic Stratigraphy. Applications to Hydrocarbon Exploration. Am. Assoc. Pet. Geol. Mem. 26, $53-62$.

Morales, J.A., 1993. Sedimentología del Estuario del Rio Guadi- 
ana (SO España-Portugal). PhD Thesis. University of Huelva, $300 \mathrm{pp}$.

Morales, J.A., 1997. Evolution and facies architecture of the mesotidal Guadiana River delta (SW Spain-Portugal). Mar. Geol. 138, 127-148.

Nelson, C.H., Maldonado, A., 1999. The Cadiz margin study off Spain: an introduction. Mar. Geol. 155, 3-8.

Nelson, C.H., Baraza, J., Maldonado, A., Rodero, J., Escutia, C., Baraber, J.H., 1999. Influence of the Atlantic inflow and Mediterranean outflow currents on Late Quaternary sedimentary facies of the Gulf of Cadiz continental margin. Mar. Geol. $155,99-129$.

Nichol, S.L., Zaitlin, B.A., Thom, B.G., 1997. The upper Hawkesbury River, New South Wales, Australia: a Holocene example of an estuarine bayhead delta. Sedimentology 44, 263-286.

Pendón, J.G., Morales, J.A., Borrego, J., Jiménez, I., López, M., 1998. Evolution of estuarine facies in a tidal channel environment, SW Spain: evidence for a change from tide to wavedomination. Mar. Geol. 147, 43-62.

Rambaud, F., 1996. Portus Gaditanus. Hipótesis de un nuevo emplazamiento. Rev. Arqueol. (Madrid) 187, 28-35.

Richards, M.A., 1994. Transgression of an estuarine channel and tidal flat complex: the Lower Triassic of Barles, Alpes de Haute Provence, France. Sedimentology 41, 55-82.

Riggs, S.R., Cleary, W.J., Snyder, S.W., 1995. Influence of inherited geologic framework on barrier shoreface morphology and dynamics. Mar. Geol. 126, 213-234.

Rodero, J., Pallarés, L., Maldonado, A., 1999. Late Quaternary seismic facies of the Gulf of Cadiz Spanish margin: depositional processes influenced by sea-level change and tectonic controls. Mar. Geol. 155, 131-156.

Rodríguez Ramírez, A., Rodríguez Vidal, J., Cáceres, L., Clemente, L., Belluomini, G., Manfra, L., Improta, S., De Andres, J.R., 1996. Recent coastal evolution of the Doñana National Park (SW Spain). Quat. Sci. Rev. 15, 803-809.

Rodríguez Vidal, J., 1987. Modelo de evolución geomorfológica de la Flecha Litoral de Punta Umbría, Huelva, España. Cuat. Geomorfol. 1, 247-256.

Roy, P.S., 1994. Holocene estuary evolution. Stratigraphic studies from southeastern Australia. In: Dalrymple, R.W., Boyd, R., Zaitlin, B.A. (Eds.), Incised-Valley Systems: Origin and Sedimentary Sequences. Soc. Econ. Paleontol. Mineral., Spec. Publ. 51, 241-263.

Sánchez-Arcilla, A., Smith, D., 1998. Sea-level rise research in Europe: state of the art and future research needs. J. Coastal Res. 14, 1184-1186.

Sanlaville, P., Dalongeville, R., Bernier, P., Evin, J., 1997. The Syrian coast: a model of Holocene coastal evolution. J. Coastal Res. 13, 385-396.

Sierro, F.J., Flores, J.A., Baraza, J., 1999. Late glacial to recent paleoenvironmental changes in the Gulf of Cadiz and formation of sandy contourite layers. Mar. Geol. 155, 157-172.

Skene, K.I., Piper, D.J.W., Aksu, A.E., Syvitski, J.P.M., 1998. Evaluation of the global oxygen isotope curve as a proxy for Quaternary Sea level by modeling of delta progradation. J. Sediment. Res. 68, 1077-1092.

Somoza, L., Hernandez-Molina, F.J., De Andres, J.R., Rey, J.,
1997. Continental shelf architecture and sea-level cycles: Late Quaternary high-resolution stratigraphy of the Gulf of Cadiz, Spain. Geo-Mar. Lett. 17, 133-139.

Somoza, L., Barnolas, A., Arasa, A., Maestro, A., Rees, J.G., Hernández-Molina, F.J., 1998. Architectural stacking patterns of the Ebro delta controlled by Holocene high-frequency eustatic fluctuations, delta lobe switching and subsidence processes. Sediment. Geol. 117, 11-32.

Stanley, D.J., 1995. A global sea-level curve for the Late Quaternary: the impossible dream?. Mar. Geol. 125, 1-6.

Suárez Bores, P., 1971. Determinación de la edad mediante medidas del contenido carbono-14, en muestras de conchas procedentes de los litorales de Huelva y Valencia. Gabinete de Aplicaciones Nucleares a Obras Públicas, Madrid, 17 pp.

Vail, P.R., Mitchum, R.M., Thompson, S., III, 1977. Part 4. Global cycles of relative changes of sea level. In: C.E. Payton (Ed.), Seismic Stratigraphy - Applications to Hydrocarbon Exploration. Am. Assoc. Pet. Geol. Mem. 26, 83-97.

van Geen, A., Adkins, J.F., Boyle, E.A., Nelson, C.H., Palanques, A., 1997. A 120 yr record of widespread contamination from mining of the Iberian pyrite belt. Geology 25, 291-294.

Vanney, J.R., Menanteau, L., 1985. Mapa físiográfico del litoral atlántico de Andalucía. 1:50,000. M.F. 02: Punta UmbríaMatalascañas y M.F. 03: Matalascañas-Chipiona. Junta de Andalucía, Consejería de Política Territorial, $48 \mathrm{pp}$.

van Wagoner, J.C., Posamentier, H.W., Mitchum, R.M., Vail, P.R., Sarg, J.F., Loutit, T.S., Hardenbol, J., 1988. An overview of the fundamentals of sequence stratigraphy and key definitions. In: Wilgus, C.K., Hastings, B.S., Kendall, C.G. St. C., Posamentier, H.W., Ross, C.A., Van Wagoner, J.C. (Eds.), Sea-Level Changes: An Integrated Approach. Soc. Econ. Paleontol. Mineral., Spec. Publ. 42, 39-45.

Willis, B.J., 1997. Architecture of fluvial-dominated valley-fill deposits in the Cretaceous Fall River formation. Sedimentology 44, 735-757.

Zaitlin, B.A., Dalrymple, R.W., Boyd, R., 1994. The stratigraphic organization of incised-valley systems associated with relative sea-level change. In: Dalrymple, R.W., Boyd, R., Zaitlin, B.A. (Eds.), Incised-Valley Systems: Origin and Sedimentary Sequences. Soc. Econ. Paleontol. Mineral., Spec. Publ. 51, 4560.

Zazo, C., Dabrio, C.J., Goy, J.L., Meco, J., 1992. Evolution of the littoral lowlands of Huelva and Cadiz (Gulf of Cadiz, SW Spain) from the Flandrian until present. In: Suarez de Vivero, J.L. (Ed.), The Ocean Change: Management Patterns and the Environment. Servicio de Publicaciones and Departamento de Geografia Humana, Universidad de Sevilla, 27-38.

Zazo, C., Goy, J.L., Dabrio, C.J., Bardají, T., Somoza, L., Silva, P.G., 1993. The last interglacial in the Mediterranean as a model for the present interglacial. Global Planet. Change 7 , 109-119.

Zazo, C., Goy, J.L., Somoza, L., Dabrio, C.J., Belluomini, G., Improta, J., Lario, J., Bardají, T., Silva, P.G., 1994a. Holocene sequence of sea-level fluctuations in relation to climatic trends in the Atlantic-Mediterranean linkage coast. J. Coastal Res. 10, 933-945.

Zazo, C., Lario, J., Goy, J.L., Lézine, A.M., Faure, H., Dabrio, 
C.J., Somoza, L., Borja, F., 1994. Late-Pleistocene and recent Holocene rapid coastal changes in South Iberia. First International Meeting Late Quaternary Coastal Records of Rapid Change, IGCP Project 367. Symposium Abstracts, 1 p.

Zazo, C., Dabrio, C.J., Goy, J.L., Bardaji, T., Ghaleb, B., Lario, J., Hoyos, M., Hillaire-Marcel, C., Sierro, F.J., Flores, J.A., Silva, P.G., Borja, F., 1996a. Cambios en la dinámica litoral y nivel del mar durante el Holoceno en el Sur de Iberia y Canarias Orientales. Geogaceta 20, 1679-1682.

Zazo, C., Lezine, A.M., Borja, F., Denèfle, M., Dabrio, C.J., Lario, J., Rodríguez Vidal, J., Goy, J.L., Bardají, T., Díaz del Olmo, F., Cáceres, L., Clemente, L., Baeteman, C., Rodríguez Ramírez, A., 1996b. Holocene coastal progradation changes and peat bog development in SW Spanish coast. Int. Union Quat. Res., Subcommis. Mediterr. Black Sea Shorelines Newslett. 18, 13-17.
Zazo, C., Goy, J.L., Hillaire-Marcel, C., Hoyos, M., Cuerda, J., Ghaleb, B., Bardaji, T., Dabrio, C.J., Lario, J., Silva, P.G., González, A., González, F., Soler, V., 1997. El nivel del mar y los interglaciares cuaternarios. Su registro en las costas peninsulares e insulares españolas. In: Rodríguez-Vidal, J. (Ed.), Cuaternario Ibérico. Universidad de Huelva, 23-32.

Zazo, C., Dabrio, C.J., Borja, F., Goy, J.L., Lezine, A.M., Lario, J., Polo, M.D., Hoyos, M., Boersma, J.R., 1997. El acantilado del Asperillo, parada 2. Costa oriental de Huelva. Excursión A. In: Rodríguez-Vidal, J. (Ed.), Guía de Campo, 4th Reunión de Cuaternario Ibérico. Universidad de Huelva, 29-32.

Zouari, K., Gibert, E., Causse, C., 1998. Radiocarbon and Th/U chronologies of humid episodes of Late Quaternary from Sahara selected sites of PALHYDA Programme. In: Causse, C., Gasse, F. (Eds.), Hydrology and Isotope Geochemistry. ORSTOM Éditions, Paris, France, 177-195. 